\title{
The Development of the Pollen-tube and the Division of the Generative Nucleus in certain Species of Pines.
}

\author{
BY
}

\author{
MARGARET C. FERGUSON ${ }^{1}$.
}

With Plates XII, XIII, and XIV.

\section{INTRODUCTORY.}

THERE is perhaps no phase of botanical science to which 1 greater interest attaches at the present day than that which is concerned with the problems of sexual reproduction. The early botanists found in this question merely a favourite subject for philosophical speculation. Although Amici ('30'46) made certain interesting observations regarding the development of the pollen-tube and the origin of the embryo in several plants, yet Hofmeister ('46-'62), whose works have already become classic, will ever be recognized as the first true scientific investigator along the line of sexual reproduction in plants. Since his studies, many botanists have found in this subject an attractive field for investigation. The celebrated discoveries of Ikeno, Hirase, and Webber, in I897, gave a new incentive to this study, particularly in connexion with

1 Read before the Botanical Society of America at its sixth annual meeting in New York City, June 28, I900.

[Annals of Botany, Vo1. XV. No. LVIII. June, I90I.] 


\section{Ferguson.-Development of the Pollen-tube and the}

the Gymnosperms, and rendered it highly desirable that fertilization and associated phenomena should be worked out for other members of this group by the more modern methods of investigation.

The present studies were undertaken in the fall of 1897 . They have been carried on in the botanical laboratory of Cornell University under the direction of Professor George F. Atkinson. Professor Atkinson's interest in the work has been a constant inspiration to me, and his counsel invaluable. I also take pleasure in acknowledging my appreciation of the valuable assistance rendered by Dr. E. J. Durand.

\section{Methods.}

On November 15, I897, and each week thereafter until December 25, cones of Pinus Strobus, $P$. austriaca, $P$. rigida, and $P$. montana, var. uncinata, were collected, and ovules preserved. Material was fixed occasionally during the remainder of the winter. Beginning with April I, the species named above and also Pinus resinosa were collected once each week. Collections were made twice each week during the month of May and three times a week for June. From June 10-30, a period which was sure to cover fertilization, cones of Pinus Strobus were collected every day at about nine o'clock in the morning, and frequently again at four in the afternoon. During May and June the little young cones were collected for each species as well as the more mature cones of the previous year's growth. After July I, the older cones were no longer collected, but the young cones of Pinus Strobus, $P$. austriaca, and $P$. rigida were collected once each week until November I5. Cones of Pinus Strobus were again collected regularly, as described above, during the spring and early summer of 1899 .

Each time of collecting, ovules were put up from several cones of each species, and these cones were not taken from the tip of one branch, but from different branches. Ovules were fixed from the central portion only of the cones. In the first stages of development the cones were fixed entire 
or cut into quarters longitudinally. Very soon the individual scales were removed from the receptacle before fixing, and, when the scales were of sufficient size to admit of such manipulation, all superfluous parts were cut away, leaving the two tiny ovules still united by a small portion of the scale. In the spring the ovules were removed from the scales and, as soon as it was feasible, a portion of the integument was cut away from two or more sides of each ovule. For later stages the endosperms were frequently removed, but such material did not prove to be as satisfactory as that in which the nucellar cap and a small portion of the integument were left in connexion with the prothallium. Throughout the entire mechanical process of preparing material for the fixer, the most extreme care was used, as it was found that a very slight pressure was sufficient to cause distortions and thus render the material worthless for cytological studies.

The methods used in fixing and staining do not differ materially from those generally employed in cytological work. Several fixing fluids were tried, but the Flemming chromosmo-acetic acid solution gave by far the best results, and the other fixers were entirely discarded. The material was embedded in paraffin which had a melting point of $54^{\circ}$ and was cut on a Minot-Zimmermann revolving microtome. Some sections were cut four, others thirteen and one-third, microns thick; but by far the greater part of the material was cut six and two-thirds microns thick.

Various stains were tried, among which might be mentioned Rosen's ('92) fuchsin and methylene-blue method; the EhrlichBiondi-Heidenhain mixture, as prepared by Dr. G. Grübler; Guignard's combination of methyl green, acid fuchsin, and orange $G$ (Guignard has not given the formula which he uses and hence solutions of various strengths were tried); Flemming's safranin, gentian-violet and orange combination; and Heidenhain's iron-haematoxylin. The last two proved the most satisfactory. Flemming's triple stain was often used without the safranin with excellent results. The iron-haematoxylin was followed by orange $G$, or if it was desirable to

$\mathrm{O} 2$ 


\section{I96 Ferguson.-Development of the Pollen-tube and the}

stain cell-walls, by Bismarck brown. Iron-haematoxylin, followed by Flemming's triple stain or by gentian-violet, and orange $\mathrm{G}$, brought out the so-called kinoplasmic structures with great definiteness.

During the course of these investigations more than three thousand ovules have been sectioned, stained, and studied. The present paper is concerned only with the development of the pollen-tube; fertilization and associated phenomena will be considered in a second paper which is to appear subsequently.

\section{HISTORICAL.}

Comparatively few students have occupied themselves with the growth of the pollen-tube in the Abietineae, and no one, in so far as I have been able to determine, has described the cytological features attending the formation of the spermnuclei in this group.

In 1862 Hofmeister described and figured the pollen-grain in the Abietineae as consisting of a cell-complex, noted the depression at the apex of the nucellus in Pinus at the time of pollination, and traced the pollen-tube into the corpusculum. He also figured the pit in the apex of the pollen-tube which, however, he said remained closed until after the formation of the proembryo, when it was ruptured by mechanical means. Hofmeister further observed what were doubtless the spermnuclei at the apex of the pollen-tube, but he did not understand their function and was unable to determine their later history.

The works of Strasburger on this subject have been more numerous and complete than those of any other investigator. It is extremely interesting to note how his interpretations have kept pace with the improvements in methods of research. In 1869 he followed the pollen-tube into the corpusculum in Pinus and Picea and confirmed Hofmeister's observation regarding the presence of a closed pit at the apex of the pollen-tube; but he did not observe the nuclei in the pollentube, and remarked that inasmuch as the sexual organs touch 
in these plants, spermatozoids would be superfluous and are, in reality, not present. He added, however, that their place is taken by granular protoplasm and starch-grains which exercise the same fertilizing effect on the egg as do spermatozoids. In 1872 Strasburger detected two cells in the pollen-tube of several Gymnosperms, but considered that such cells were extremely rare in the Abietineae, as he had only once found one in this group. The shrunken remains of these cells were seen in the pollen-tube after fertilization. He thought that the pit of the pollen-tube remained closed, and that the exchange-substance was apparently communicated by a vacuole between the apex of the pollen-tube and the egg-nucleus. Six years later ('78) he observed two nuclei in the pollen-tube of Pinus and Picea when the tube was just above the archegonium. According to his interpretation at that time, the nucleus in front was dissolved while the one behind entered the egg and fused with its nucleus. This was a great advance on his previous observations; but he still conceived of the pollen-tube as remaining closed, and fancied that the protoplasmic contents passed through the membrane directly, while the starch was dissolved before its transmission into the egg. In the following year ('79) he established the fact that it is the foremost of the two spermnuclei in the pollen-tube which becomes active in fertilization.

Goroschankin ('83) saw the two sperm-nuclei pass into the egg in Pinus Pumilio, and he believed that both fused with its nucleus. Strasburger ('84) confirmed his observation as to the passage of the two sperm-nuclei from the pollen-tube into the egg, but pointed out that only the one in advance fuses with the egg nucleus.

It was left for Belajeff ('91) to establish the true nature of the cell-complex found in the pollen-grain of the Gymnosperms. He demonstrated the fact that in Taxus baccata the large nucleus of the pollen-grain is the vegetative or pollen-tube nucleus, as in the Angiosperms, and that the sperm-nuclei arise by the division of one of the smaller cells of the pollengrain. This smaller cell divides to form the stalk- and the 
generative cell. The latter cell passes into the pollen-tube before giving rise to the sperm-nuclei.

Strasburger ('92) showed that Belajeff's observations on the development of the pollen-tube in Taxus baccata were in general true for the other Gymnosperms. He described the - mature pollen-grain in Pinus sylvestris, noted that the vegetative nucleus passes into the pollen-tube immediately upon germination, and remarked that the last formed prothallial cell remains in its place in the pollen-grain until the following spring, when it divides into the stalk- and the body-cell of the antheridium. The division of this cell was not studied, but Strasburger thought it took place at about the same time as the development of the archegonia. He also stated that the lower sperm-cell is the larger, and described each cell as being almost entirely filled with its large, coarsely granular nucleus.

Belajeff ('93) worked out the development of the pollentube in Picea as a type of the Abietineae. He found that the generative cell divides while still in the pollen-grain, and gives rise to two sperm-cells which he figured as of the same size.

Dixon ('94) traced the history of the pollen-grain and the pollen-tube in Pinus sylvestris from the time of pollination to fertilization. According to his observations Pinus agrees in the main with Picea, as described by Belajeff. In general I cannot confirm Dixon's results, and they will be considered more fully in the body of this paper.

In giving an account of some work done by his students on the Gymnosperms, Coulter ('97) reported that the work of Dixon 'was largely confirmed in the minutest detail,' and in 1900 he figured the pollen-tube 'in pines,' when just above the archegonium, showing two sperm-cells of equal size.

Blackman ('98) did not study the growth of the pollen-tube, but accepted Dixon's work as authoritative.

Professor Atkinson ('98) stated that the sperm-mother-cell in Pinus divides into two sperm-cells after having passed into the pollen-tube. 


\section{Pollination.}

In the vicinity of Ithaca pollination takes place in the pines during the latter part of May or the first week in June, the different species varying a few days. When the pollengrains have been drawn into the depression in the upper part of the nucellus, the projecting portions of the integument close over them and a resinous substance is secreted which practically seals the opening by which the pollen-grains entered (Plate XII, Figs. I and 7). At this time the pollen-grain contains, as described by Strasburger ('92), the remnants of two prothallial cells; one small cell, the third prothallial cell formed, or the antheridial cell ; and a large cell, the vegetative or wall-cell (Fig. 6).

The degree of development which the ovule has attained at the time of pollination is shown in Fig. I. The central portion of the nucellus is occupied by an axial row of cells, the lowest of which is in the early prophase of division (the figure is drawn on too small a scale to show this distinctly); and the two upper nuclei are in a process of disintegration, as indicated by their diffuse reaction to stains. Frequently only the first cell of the axial row, the macrospore of Hofmeister, is present at this time. The so-called spongy or loose tissue of Strasburger is already well differentiated when pollination takes place.

The upper concave portion of the nucellus which, together with the enveloping integument, forms the pollen-chamber, terminates in a row of more or less elongated cells which are not closely united at their free extremities, but stand out, as it were, like so many fingers to catch the pollen-grains; they also serve to facilitate the entrance of the pollen-tube into the tissue of the nucellus (Fig. 7).

\section{Development of the Pollen-tube.}

The germination of the pollen-grain takes place very soon after pollination. The pollen-grain increases slightly in size, the concave portion of the wall (d, Fig. 6$)$ becomes convex, 
then bulges out, the exospore is ruptured, and the endospore is gradually prolonged into a tube. Immediately upon the formation of the pollen-tube, the vegetative nucleus, as shown by Strasburger ('92), moves away from the antheridial cell and towards the tip of the pollen-tube (Figs. 7 and 8). Strasburger ('92) describes the antheridial cell in Pinus sylvestris as remaining unchanged until the archegonia are formed in the following spring. Dixon states that it divides about a month before fertilization, but from a careful reading of the text, one is given the impression that this was an inference on his part rather than a demonstrated fact. In some species of pines the division of this cell certainly takes place very much earlier. During the first week in August there have been found on the nucellus, in Pinus Strobus, pollengrains containing two cells (Fig. I0). In such instances the vegetative nucleus can invariably be detected in the pollentube. In the same material, other pollen-grains are observed in which the division of the antheridial cell has not yet taken place; but in material fixed somewhat later, it is only rarely found undivided. In Pinus austriaca this division also takes place during the summer. I once found the mitotic figure for the division of the antheridial cell in Pinus resinosa on the first of April. As this was the earliest date on which material of this species had been collected, I am unable to determine at present whether or not it is the normal time for the division in Pinus resinosa.

A pollen-grain with its antheridial cell still undivided has been observed just prior to fertilization (Fig. 5). In this case two of the three pollen-tubes which have almost reached the prothallium are furnished with sperm- and stalk-cells, while in the third, only the vegetative nucleus is found. On the apex of the nucellus there is a pollen-grain which at this late date contains one cell, the antheridial cell, still undivided. The nucleus of this pollen-grain (Fig. $5 b$ ) is large, plump, and to all appearances perfectly normal, and it is possible, though scarcely probable, that it may still divide. That one cannot trace a definite connexion between the pollen-tube containing 
only the vegetative nucleus and this pollen-grain signifies little, for those who have studied the pollen-tube of Pinus know that it is the exception rather than the rule when a given pollen-tube can be traced through the lacerated dead tissue of the upper portion of the nucellus to the pollen-grain from which it proceeded. Such a condition as that just described is rarely met with at so late a date. But occasionally during the summer and fall pollen-grains are found in which no cell-division has taken place since pollination, although in the majority of cases the stalk- and the generative cell have already been formed. These observations seem to indicate that, while the division of the antheridial cell takes place comparatively soon after the pollen-grain has germinated in Pinus Strobus and P. austriaca (other species have not been studied with regard to this point), it may under certain conditions be much delayed, and in some cases, doubtless, never takes place at all. This question can only be decided by actual observation of the mitotic figure at different periods of the year. Meanwhile, we know that in Pinus Strobus and $P$. austriaca at least, the stalk- and the generative cell are formed as a rule before the approach of winter. At first these two cells are very similar, but the generative cell soon increases somewhat in size (Figs. Io and II).

A vertical section of an ovule collected on Jan. 4 is represented in Fig. 2. The spongy tissue surrounds a cavity crossed by irregular strands of protoplasm in which the free nuclei of the prothallium are embedded. The stalk and the generative cell are enclosed within the pollen-grain, and the vegetative nucleus is near the apex of the irregularly branched pollen-tube. This pollen-tube is shown more highly magnified in Fig. I2. At this time the pollen-tubes have penetrated the nucellus almost to the point at which it joins the free limb of the integument. The greatest depth to which the tubes may have grown is not indicated in the illustration. The section was figured because it shows most clearly the cells of the pollen-grain and tube. Other sections 
of the same ovule would have shown pollen-tubes which had pierced to a greater depth into the nucellus. The conditions of development as figured for January coincide perfectly with those which exist during the latter part of October.

Growth is very slow during the first period of development, but with the renewed activities of spring the ovule increases rapidly in size; the central cavity of the nucellus becomes greatly enlarged and is lined with the growing endosperm. The prothallium now consists of a uniform layer of protoplasm in which numerous free nuclei are embedded, no cell-walls as yet having been laid down. Immediately surrounding the endosperm, there is a definite band or hollow sphere of cells which is limited on its outer surface by a thin stratum of the disintegrating nucellus. These two layers constitute the so-called spongy tissue. The inner portion of this tissue, i.e. the prominent band in immediate contact with the prothallium, must be intimately connected with the nutrition of the young endosperm. The true structure and function of this layer seem to have escaped the notice of previous writers. Its cells contain large nuclei, and are abundantly supplied with protoplasm. The karyokinetic figures so frequently observed in these cells show that this tissue increases in size by the growth and division of its cells, as do the other portions of the ovule. As it enlarges, the cells of the nucellus in contact with its outer surface become disorganized and are absorbed (Fig. 3).

The cells of the nucellar cap which were penetrated by the pollen-tubes during the previous season do not again become active, but remain as deeply staining, thick-walled, dead cells. The cells just beneath them, however, multiply rapidly, and become literally packed with starch. A few of the cells from this region in Fig. 5 are shown more highly magnified in Fig. I8. By the growth and increase of these cells, the dead top of the nucellus with its pollen-tubes is lifted far above the developing endosperm, so that the pollentubes, once so near their goal, are now removed from it by a considerable distance (Figs. 2-4). Meanwhile the pollen- 
tube has increased little, if at all, in length, renewed activity in the male gametophyte being first indicated by a further development of the cells still within the pollen-grain.

The stalk-cell increases in size and its cytoplasm assumes a vacuolate character. The growth of the generative cell is still more marked, and its cytoplasm on the contrary becomes dense and deeply staining. (Compare Fig. I2, Jan. 4, with Fig. 13, May 3.) In Pinus sylvestris, as studied by Dixon, the generative cell divides while it is within the pollen-grain. In the species of pines which I have investigated, this division does not occur until the generative and the stalk-cell have entered the pollen-tube, and the stalk-cell has passed below the generative cell. As the generative cell increases in size it stretches out towards and into the neck of the pollen-tube, drawing after it the stalk-cell, or possibly being forced out by this cell, the two passing into the tube together. Dixon states that only the naked nucleus of the stalk-cell enters the pollen-tube, and in so far as I am aware, no writer has described the entrance of the entire stalk-cell into the pollentube in the Abietineae. The material which I have studied shows conclusively that the nucleus does not 'slip out' of its cytoplasm (Figs. 12-I5). The entire cell can be identified in the tube and later in the egg. During the time that this cell is moving over the generative cell its cytoplasm cannot always be clearly differentiated from that of the latter; but when once the stalk-cell has passed the generative cell, its nucleus surrounded by a sphere of very vacuolate cytoplasm, scarcely more than a peripheral layer, is again distinctly demonstrated. After passing the generative nucleus, the stalk-cell ordinarily takes up a position between the generative cell and the vegetative nucleus (Plate XIII, Fig. 2I); occasionally it may pass the vegetative nucleus (Fig. 22).

When the generative cell leaves the pollen-grain, its nucleus is situated near the top of the cell, but it apparently moves faster than does the accompanying cytoplasm, and when the stalk-cell passes the generative nucleus, this nucleus lies at or below the centre of its cell (Figs. I3, I9, and 20). Shortly 


\section{Ferguson.-Development of the Pollen-tube and the}

after this the generative nucleus is again observed at the uppermost part of its cytoplasm (Figs. 2I and 22).

During its passage into the tube, the generative cell increases much in size; it has no definite cell-wall, and its cytoplasm forms a large, irregular tongue about the nucleus. This cytoplasm in no way suggests the alveolar structure of Buitschli ('94), but is distinctly reticular, differing in appearance from the nuclear net only by its greater delicacy. This is shown more clearly at a somewhat later stage.

The vegetative and generative nuclei are now very similar in structure, though each is sufficiently characteristic to be readily recognized by one who is familiar with them. The vegetative nucleus has one large, usually homogeneously staining nucleolus, rarely one or more smaller nucleoli, and it is furnished with a rather scanty, delicate reticulum which is apparently poor in chromatin. Either it is in a state of more or less collapse, or it is very hard to fix at this period, for its outline is as a rule quite irregular. The generative nucleus has one large, hollow or vacuolate nucleolus, and commonly two smaller ones; its reticulum, though more abundant than that of the vegetative nucleus, is still delicate and often shows a weak reaction to nuclear stains. The stalk-nucleus has a very decided individuality which it maintains throughout its entire history. It bears a strong resemblance from the first to the nuclei of the nucellar tissue, rarely, if ever, contains a true nucleolus, and its close-meshed reticulum is conspicuous for its comparatively large net-knots or karyosomes.

\section{Division of the Generative Nucleus.}

Dixon ('95) describes this division in Pinus sylvestris as taking place about a month before fertilization, while the generative cell is still within the pollen-grain; and Coulter ('97) states, as already mentioned, that in his study of Pimus Laricio he has been able to confirm Dixon's observations. At this time, as pointed out by Dixon, the nuclear and cytological phenomena are very greatly obscured by the 


\section{Division of the Generative Nucleus in Pines. 205}

presence in the pollen-tube of large quantities of starch (Fig. 20). This starch, which resists the microtome knife and is therefore easily displaced by it, not infrequently falls out and carries away with it the free cells of the pollen-tube. The dead, deeply staining tissue of the nucellus, representing that portion of the nucellar cap which was penetrated by the pollen-tube during the previous season, and in which the generative cell divides (Fig. 4), is also very troublesome. Furthermore the dense cytoplasm of the generative cell shows a great affinity for stains, so that when the archegonia and other portions of the ovule are well stained, this cell often appears merely as a deeply stained mass of no significance. Considering these facts, it is not surprising that seven hundred slides of serial sections were made, which means that more than two thousand pollen-tubes were studied, before any definite clue was obtained as to the true sequence of events in the development of the pollen-tube. When once the mitotic figure was observed in the pollen-tube, scarcely more than a week before fertilization, and the fact noted that special staining was necessary in order to study this mitosis satisfactorily, further research was prosecuted with comparative ease.

After the generative cell has passed into the pollen-grain, but while it is still in the upper dead portion of the nucellus, it gives rise to the sperm-nuclei by a division which presents some new and interesting features, while it resembles to a greater or less degree certain mitoses described by various cytologists ${ }^{1}$ during the past few years.

When the generative nucleus has again come to lie in

1 Of the long list which might be mentioned I have noted only the following : Guignard ('91) in the embryo-sac of Lilium; Rosen ('95) in the root-tip of Hyacinth; Osterhout ('97) in Equisetum ; Swingle ('97) Sphacelariaceae; Schaffner ('98) in root-tip of Allium Cepa; Mottier ('98) in the embryo-sac of Lilium; Fulmer ('98) in pine seedlings; Hof ('98) in Ephedra and other plants; Nemec ('98 and '99) in various plants; Strasburger ('00) in Vicia Faba, and Mottier ('00) in Dictyota. Of animal-cytologists I will mention but one: Hertwig, R., ('98) in Actinosphaerium. This division in Actinosphaerium bears in certain stages of its prophase a most striking resemblance to an early prophase of the mitosis about to be described. 


\section{Ferguson.-Development of the Pollen-tube and the}

the extreme upper portion of its cell, certain changes in the cytoplasm indicate that division is being initiated. At some little distance below the nucleus the cytoplasm shows a finely granular structure which is not at this stage dense nor deeply staining. From this region irregular granular threads arise which extend outward towards the periphery of the cell, those extending in the direction of the nucleus forming a hollow cone over its lower portion (Fig. 23). Gradually the granular area increases in density and in staining capacity, at the same time drawing nearer to the nucleus which is separated from it by a hyaline court. Into this court delicate granular threads pass (Fig. 24). When these threads reach the nuclear membrane, the nucleus is forced so close against the peripheral layer of cytoplasm that its wall is frequently indented on the upper side, while the condensation from which the so-called kinoplasmic threads arise withdraws, or is forced by the growth of the threads, further from the nucleus. A great number of delicately anastomosing threads now extend, in the form of a solid cone, from a point within the granular condensation up towards and against the nucleus. The outer threads of the cone pass over the lower portion of the nucleus and appear in sections of the cell as closely packed against either side of the nucleus. At the same time, the entire cytoplasmic reticulum has assumed a more or less radial arrangement, into which some of the more delicate threads extend (Fig. 25).

Co-ordinately with these changes in the cytoplasm, the chromatin of the nuclear net collects in spherical or irregular masses on the reticulum, and sooner or later gives rise to a broad spirem, along which the chromatic disks are distributed at regular intervals (Figs. 23-26). Whether the formation of this spirem precedes or follows the penetration into the nuclear cavity of the achromatic threads seems to depend upon the length to which these threads attain. They may become very long when their entrance into the nucleus is delayed; but more frequently a portion of the nuclear membrane gives way, and some of the achromatic fibres pass into 
the nuclear cavity before the spirem is established (Figs. 26 and 29). Rarely, the nuclear membrane appears pushed in irregularly along its entire lower margin, as indicated in Figs. 25 and 26 ; as a rule, however, there seems to be one deep, sharp indentation along one side of which the nuclear wall first gives way (Figs. 27 and 29). With the initial steps in the disappearance of the nuclear membrane the nucleolus is either not apparent or, if still demonstrable, it stains but feebly. When the membrane disappears along the entire lower portion of the nucleus, the kinoplasmic threads press so closely against it that it cannot be definitely demonstrated whether it passes into the cytoplasmic and the nuclear reticulum or becomes fibrous and contributes to the formation of the achromatic threads (Figs. $28 b$ and 29). The threads which have been packed so closely against the wall of the nucleus now press into the nuclear cavity and mingle with those which have entered from below; and the dense, granular, cytoplasmic area from which the threads diverge is gradually dissipated (Fig. $3^{\circ}$ ).

In the early stages of mitosis it is evident that there are present in the nuclear reticulum two kinds of granules, as described by Heidenhain ('93 and '94). This becomes more apparent as the chromatin condenses to form the spirem. When the spirem is fully differentiated there is present in the nuclear cavity a loose, granular, achromatic reticulum. With the disappearance of the wall along the lower part of the nucleus this network seems to undergo a partial rearrangement. A portion of it is resolved into threads of more or less regularity, which in general assume a position parallel to the threads entering the nuclear cavity; some of them become attached directly to the ends of these fibres, and doubtless contribute to their growth (Figs. 29-31).

As the spindle-threads proceed in their development across the nucleus, the chromatic spirem collects in the region of the future nuclear plate, and becomes more or less massed together, presenting an appearance somewhat comparable with that of synapsis; at the same time it becomes homogeneous 
and gives rise by segmentation to the chromosomes (Figs. 30-33). Some of the ingrowing spindle-threads may extend across the nucleus to the nuclear membrane, which is still present on the upper side of the nucleus; but by far the greater number unite some distance below this membrane to form several poles, thus giving rise to a diarch spindle (Strasburger, 1900), which is multipolar at its upper extremity; and unipolar, or nearly so, at its lower end. Gradually the poles of the upper portion draw together, while the spindle is somewhat shortened by the lower extremity of the threads being again resolved into granules. Finally a true bipolar diarch spindle is formed with the V-shaped chromosomes oriented at the nuclear plate. Each pole terminates in a slight granular condensation. The upper pole has never been observed to reach to the nuclear membrane, but frequently coarse granular threads extend from the pole to the wall of the nucleus, and apparently act as supports (Fig. 34). These are doubtless formed by a rearrangement of the linin reticulum. The nuclear membrane persists along the upper part of the nucleus until the late teleophase of the division (Pl. XIII, Figs. 30-35, and Pl. XIV, Fig. 38).

As the chromosomes pass to the poles, the central spindle elongates so that the daughter-nuclei are separated, as a rule, by a greater distance than the original length of the spindle. While this is characteristic of cell-division in general, it is occasionally much exaggerated here, the daughter-nuclei being apparently forced apart with considerable energy. The nucleus which occupies the position nearest to the micropylar end of the ovule usually shows a deep indentation along its upper surface as if a resistance had been met with in the peripheral layer of cytoplasm (Figs. 4I and 42). Not infrequently the upper nucleus is found almost entirely separated from the cytoplasm (Fig. 43). This, however, may be due to mechanical rupture during sectioning and staining. No cell-wall is ever formed, and in only one instance was a condensation of the spindle-threads in the region of the cell-plate observed (Fig. 40). The spindle may become 
contracted at or near its centre during its disintegration, thus presenting the appearance of an hour-glass, or it may give rise to such a condition as that shown in Fig. 42. This figure with various modifications is not uncommon. I am unable to trace its origin definitely, but it is not improbable that it is caused by a contraction of the cytoplasm resulting from a cessation of the force which tends to separate the daughter-nuclei ; or it may be caused by the resistance which the peripheral layer of cytoplasm, along the outer surface of the upper nucleus, offers to the growing fibres, thereby forcing them back upon themselves as shown in the figure. When all traces of the spindle have disappeared, the two spermnuclei are surrounded by a common mass of cytoplasm.

The mitosis just described seems to be unique as regards the origin and development of the achromatic spindle. The most exaggerated instance of asymmetry in spindle-formation which I have found recorded is that described and figured by Nemec $(' 99,2)$ in Solanum tuberosum. Here the nucleus lies at one side of the cell, and the spindle-fibres are very much more prominent on the free side of the nucleus than on the side adjacent to the cell-wall. In another paper Nemec $(' 99,3)$ shows by experimentation that the form of the figure which gives rise to the extranuclear spindle depends upon external forces or conditions. In the case of the pines studied, the position of the generative nucleus is such that the spindle if extranuclear in origin must of necessity be unipolar, since there is no cytoplasm, or almost none, above the nucleus from which fibres could arise.

The blending of the linin reticulum with the cytoplasmic network after the disappearance of the lower portion of the nuclear membrane, and the relation of certain portions of the achromatic nuclear reticulum to the ingrowing fibres, suggest an intimate relation between these structures. That the spindle-fibres which originate in the cytoplasm and apparently grow by a differentiation of its network are later fed by the linin of the achromatic nuclear reticulum there seems little room for doubt. In fact, all the phenomena connected with 


\section{Ferguson.-Development of the Pollen-tube and the}

this division indicate that we are dealing, not with persistent cell-constituents, but with different manifestations of one and the same thing. In a word, we find no evidence here of the presence in the cell of a definite kinoplasmic substance. Farmer and Williams ('98) in a study of Fucus 'do not regard the kinoplasm as a persistent protoplasmic structure, but as forming the visible expression of a certain phase of protoplasmic activity.' Wilson ('99 and '00) states that the astral rays ' grow by a progressive differentiation out of the general cytoplasmic meshwork,' and he finds in the Echinoderm's egg ' no ground for a specific kinoplasm.'

Nothing has been said regarding the nature of the granular, cytoplasmic condensation from which the achromatic spindle takes its origin. It never has a definite boundary, though it is often very clearly differentiated by its dense granular appearance and its strong affinity for stains; but it may be inconspicuous or fail entirely to be demonstrated. So much has been said during the past decade regarding the nature and existence of the centrosome and the centrosphere that one feels inclined to avoid the subject entirely. Yet the question may very properly be asked, Is this condensation which forms the centre of a system of radiating fibres a centrosphere? It certainly is as clearly an attractionsphere as some figures which have been described as such; but if we accept Wilson's ('00) definition of the centrosphere, the body under consideration cannot be so denominated, as no centrosome has been observed at its centre. More deeply staining granules may sometimes be present within the condensation, but these are not considered of any significance, as such granules may be found anywhere in the cytoplasm.

Karsten ('93) describes the nucleoli in Psilotum as passing out of the nucleus and assuming the role of centrosomes, and Strasburger ('00) considers that the nucleoli not only contribute material for the formation of kinoplasmic threads, but that they also make active the spindle-forming substance in the cytoplasm-in other words, they act as the kinetic centres of the cell. There seems to be no evidence that such is the 
case here, for the nucleoli, after the condensation has arisen and the spindle-threads have attained considerable length, are morphologically the same as they were before the inception of the spindle. Nemec $(' 99,1)$ remarks that in the higher plants where the centrosome is not present, the entire nucleus may exercise the function of the centrosome. The idea of the diffused centrosome in the cells of the higher plants was suggested by Guignard ('97), and again hinted at by Le Dantec ('99). If we may accept Guignard's suggestion, then the kinetic centre of the cell in the higher plants is no longer indicated by the presence of a definite organ, the centrosome, but the power of this organ has become dissipated throughout the entire cell. When that phase of cell-activity which has to do with spindle-formation comes into play, the points at which it is centred would naturally be indicated by a greater accumulation of the microsomes, and thus an aster of more or less definiteness would be formed, as when the individualized centrosome is present. In the division under consideration, the position of the generative nucleus is such that the energy active in spindle-formation must perforce be centred at some point below it. Such a centring of activity would naturally result in an attractionsphere of unusual prominence; and there would be no occasion for its division since the spindle is unipolar in origin.

The endosperm has become a solid mass of tissue at the time when the generative nucleus divides. The details of its development will not be given here, more than to say that it resembles in many points the growth of the prothallium in Taxus baccata as described by Jäger ('99). The archegonia are still comparatively small and quite vacuolate and the central cell has not yet divided (Fig. 4).

\section{Growth of the SPERM-NUClei AND LATER HISTORY of the POLlen-Tube.}

After the mitotic figure has entirely disappeared, the spermnuclei are separated by a considerable distance; and the form which the cytoplasm surrounding them assumes seems to 
vary with the shape of the pollen-tube. Gradually the two nuclei approach each other until they come to lie in the extreme uppermost part of their cytoplasm (Figs. 47 and 48). There is now considerable difference in their size. This inequality in size could be detected as far back as the formation of the daughter-nuclei (Figs. 39 and 40). Coulter ('97) described two sperm-cells which were of the same size until within the archegonium. Blackman ('98) stated that each sperm-nucleus was clearly seen in the pollen-tube surrounded by its own cytoplasm, but he did not figure them. Chamberlain ('99) figured the sperm-nuclei, in Pinus Laricio, of equal size in the pollen-tube, and showed them lying together in the cytoplasm of the tube. Not having seen these cells within the archegonium before the conjugation of the sexual nuclei, he accepted Coulter's statement for the growth of one of them after their entrance into the egg. Two sperm-cells have not been observed in any of the pines which I have studied; but the sperm-nuclei, which are of unequal size from a very early date, remain surrounded by a common cytoplasmic body (Figs. 39-50). As Strasburger ('92) observed, the larger nucleus is always ahead, that is, on the side nearest the apex of the pollen-tube. The smaller nucleus remains close against the upper boundary of the cytoplasm and suggests the condition in Cycas (Ikeno, '98) and Ginkgo (Hirase, '98) where the stalk-nucleus is forced entirely out of the cytoplasm surrounding the generative nucleus. In this case the action is not carried to so great an extent.

Only once has the smaller sperm-nucleus been observed in advance of the larger (Fig. 44). Here it will be seen that the entire order of arrangement has been changed and the stalk-cell and the vegetative nucleus are above the sperm-nuclei. But this abnormal arrangement is only apparent, for it was found that the egg which had been approached by this pollen-tube had already been fertilized, and the pollen-tube had turned aside and was passing up over the top of the endosperm. The position of the various elements of the pollen-tube is therefore normal, and the larger sperm-cell is in reality in advance of the smaller. 


\section{Division of the Generative Nucleus in Pines. 213}

The formation of the sperm-nuclei shows very beautifully the development of the nuclear reticulum. The chromosomes unite end to end, giving rise to a homogeneous, coiled band, before the nuclear membrane is formed. When the nuclear wall has been differentiated, the coil expands about the periphery of the nucleus and the band broadens, at the same time becoming irregularly jagged along its margins. These irregularities increase in length until finally those from neighbouring portions of the thread meet and fuse, thus giving rise to the reticulum (Figs. 37-40).

When the two sperm-nuclei have nearly or quite come into contact they have as a rule reached their mature size. More than a year has now elapsed since pollination. Up to this time the pollen-tube has elongated very slowly, having penetrated as yet little beyond the nucellar tissue of the previous year's growth. In this upper portion of the nucellar cap the tube may become very broad or it may branch freely (Figs. 3, 4, 12, and 16). When the sperm-nuclei have attained their full size the downward growth of the tube is exceedingly rapid, as shown by Dixon, and the tube is unbranched and comparatively straight (Fig. 5). In Pinus Strobus and $P$. austriaca about ten days intervene between the division of the generative nucleus and fertilization; in Pimus montana, var. uncinata, the two processes are separated by an even shorter space of time.

The sperm-nuclei which at first present a very beautiful, rather delicate reticulum (Figs. 47 and 48 ), become more dense as the pollen-tube advances through the nucellus. Strasburger ('92) describes them as coarsely granular, but, with a high power, the presence of a reticulum which is sometimes coarse and interrupted can invariably be made out in wellprepared material. By the time that these nuclei have reached the central portion of the nucellar cap they have usually become very dense in structure (Figs. 46 and $46 b$ ), and frequently stain intensely, though they may show at this time a weak reaction to dyes. The reticula of the two nuclei may present the same appearance, or they may differ as in 


\section{I4 Ferguson.-Development of the Pollen-tube and the}

the figures above referred to. The nucleolus, if it be present at this time, is usually obscured by the dense network. Arnoldi ('00) describes the sperm-nuclei in Cephalotaxus as being gradually filled with metaplasm. I see no evidence of such a process in the development of these nuclei in Pinus.

When the pollen-tube reaches the egg, its apex is abundantly supplied with cytoplasm, in the upper part of which the vegetative nucleus lies. The sperm-nuclei are just above, with the stalk-cell still in contact with the lower portion of their cytoplasm. Still higher up, the tube may contain many starch grains (Fig. 50). There is never any doubt at this time as to the identity of the stalk-cell and the vegetative nucleus in the material which I have studied; but Dixon states that they cannot be distinguished, and Coulter ('97) describes them as having lost their original outline.

Archoplasmic areas similar to those figured by Chamberlain ('99) have been observed in connexion with the sperm-nuclei, but as such granular accumulations may occur at any point in the cytoplasm no importance is attached to them.

Chamberlain ('97) describes a multiplication of the normal number of cells in the pollen-grain of Lilium; and Arnoldi ('00), finding more than the usual number of nuclei in the pollen-tube of Cephalotaxus, considers that more than one vegetative or wall nucleus has been formed. I have twice observed such an excess of nuclei in Pinus. Three nuclei have been found in the pollen-grain after the vegetative nucleus has passed into the pollen-tube (Fig. 5I), and two nuclei have been seen just passing into the pollen-tube while the stalk-nucleus could still be detected in the pollen-grain, though it was almost obscured by the dead nucellar tissue and is not shown in the sketch (Fig. 45). It is not possible to determine definitely from either of these preparations to what portion of the male gametophyte the extra cells belong. Two wall-cells may have been formed or there may be present two stalk-cells; I am inclined to believe that the former is true in Fig. 45 and the latter in Fig. 5I, but in neither case can one affirm positively, and there is a possibility 


\section{Division of the Generative Nucleus in Pines. . 2 I 5}

that in both instances two generative nuclei have been formed.

When Professor Atkinson mentioned the pines as a favourable subject for investigation, he referred to the then recent discoveries of Ikeno, Hirase, and Webber, and remarked that it would be most interesting to determine whether any suggestions or remnants of a cilia-forming body (called blepharoplast by Webber in Zamia) still persist in the Conifers. Somewhat later, after the present research was begun, MacMillan ('98) pointed out the desirability of such a study both in Coniferae and Gnetales. I have seen no indication in connexion with the formation of the sperm-nuclei in Pinus of a structure which might be regarded as a reduced blepharoplast or as suggestive of a cilia-forming body of any sort. Inasmuch as spermatozoids do not exist here, such an organ, if present, must be functionless. But the cytoplasmic radiations which accompany the division, in its early stages, of the generative nucleus (Figs. 25 and 36 ), seem to differ in degree only from those found by Webber $(' 97,1)$ in the generative cell of $Z$ amia, as shown in his Figs. 3 and 5 ; and the question may be raised whether in this cytoplasmic figure we may not have still persisting in the cell the last vestiges of such an organ as that described by Webber. Neither has anything been observed throughout this study to indicate that the sperm-nuclei of Pinus ever assume the spiral or reniform shape, suggestive of spermatozoids, which has been described by recent writers ${ }^{1}$ for the sperm-nuclei in various Phanerogams. The nuclei early become spherical or elliptical in outline, depending on the breadth of the pollen-tube, and remain so during their entire later history.

\section{SUMMARY.}

I. The structure of the pollen-grain agrees fully with that described by Strasburger ('92).

2. Pollination takes place in the neighbourhood of Cornell

1 Golinski ('93) in certain grasses, Nawaschin ('99), Guignard ('99) and Sargant ('99) in Lilium, Merrell ('00) in Silphum, and Thomas ('00) in Caltha. 
University, $42 \frac{1}{2}^{\circ}$ North lat., during the latter part of May or early in June.

3. The pollen-grain germinates very soon after pollination, and the vegetative nucleus immediately passes into the tube.

4. The division of the antheridial cell takes place in Pinus Strobus and $P$. austriaca before the beginning of winter. It is probable that this cell does not always divide at a definite time, but that in a given species the time during which it may divide extends over a considerable period.

5. During the first season the pollen-tube grows very slowly, and it may be broad and irregular in outline or it may branch freely.

6. Shortly before fertilization the generative cell, followed by the stalk-cell, moves into the pollen-tube. The stalk-cell soon passes the generative cell and takes up a position near the vegetative nucleus. These changes and those immediately following are frequently much obscured by the presence in the pollen-tube of large quantities of starch.

7. The generative cell, as the other cells of the pollen-grain, is never limited by a well-defined cell-wall, and consists at the time of its division of an irregular protoplasmic body, in the upper part of which the nucleus lies.

8. In the division of the generative nucleus the spindle is extranuclear and unipolar in origin.

The formation of the spindle indicates that the cytoplasmic network and the nuclear reticulum have essentially the same structure, and the spindle-fibres are apparently formed by a transformation of both.

The nuclear membrane persists along the upper part of the nucleus until the early stages in the formation of the daughter-nuclei.

This division takes place a little more than a year after pollination and from a week to ten days before fertilization, about thirteen months elapsing between pollination and fertilization.

9. Two sperm-cells are never formed, but the sperm-nuclei remain surrounded by a common mass of cytoplasm. An 
inequality in the size of these nuclei is very early apparent, and becomes more pronounced as they reach maturity.

I0. The sperm-nuclei soon come to lie together in the upper part of their cytoplasm and early attain their full size, the larger one being invariably in advance.

The nuclear reticulum, at first delicate, soon becomes very dense, but there is no evidence of the presence in these nuclei of a special metaplasmic substance.

II. At the time when the sperm-nuclei come into contact or nearly so, the pollen-tube has penetrated little, if at all, beyond the nucellar tissue of the first year's growth. Now, however, it again begins to elongate, and its downward course through the new nucellar tissue is extremely rapid.

I2. When just above the egg, the apex of the pollen-tube is filled with cytoplasm. The vegetative nucleus lies in the upper part of this cytoplasm, and near it is seen the stalk-cell still in contact with the lower portion of the cytoplasm which surrounds the sperm-nuclei.

13. No individualized centrosome has been observed; but the existence of the diffused centrosome is suggested in connexion with the division of the generative nucleus.

14. The above summary holds good, when not otherwise indicated, for all five species of pines which I have studied. Nuclear phenomena are found to vary so much, even within the limits of a given genus, that it no longer seems safe to consider the details of development in a single plant as typical of a large group of plants. We therefore make no generalizations regarding the Abietineae. And we hesitate even to draw conclusions for the genus $P$ inus, for while the agreement in certain phases of development of five species would seem to be sufficient for the formulation of a rule, there may still exist within the genus individuals which are, in certain aspects of nuclear activity, a law unto themselves. 
2 I 8 Ferguson.-Development of the Pollen-tube and the

\section{PAPERS CITED.}

Amici, G. B., '30 : Extrait d'une lettre à M. Mirbel sur le mode d'action du pollen sur le stigmate. Ann. Sci. Nat., Bot., ${ }^{8}$ sér., tom. xxi, pp. 329-332.

'46: Sulla fecondazione delle orchidee, Atti Scienz. Ital., pp. 542549 ; republished 1847. Ann. Sci. Nat., Bot., $2^{\ominus}$ sér., tom. vii, pp. 198205.

Arnoldi, W., '00: Beiträge zur Morphologie der Gymnospermen, iii. Embryogenie von Cephalotaxus Fortunii. Flora, Bd. lxxxvii, Heft I, pp. 46-63, Taf. I-3.

Atkinson, G. F., ’98 : Elementary Botany.

BelajefF, W., '91 : Zur Lehre von dem Pollenschlauche der Gymnospermen. Ber. d. deutsch. bot. Gesell., Bd. ix, pp. 280-287, Taf. I8.

'93: Zur Lehre von dem Pollenschlauche der Gymnospermen. Ber. d. deutsch. bot. Gesell., Bd. xi, pp. I96-20I, Taf. I 2.

Blackman, V. H., '98 : On the Cytological Features of Fertilization and Related Phenomena in Pinus sylvestris, L. Phil. Trans. Roy. Soc., Series B, vol. exc, pp. 395-427, P1. I 2-I 4.

Bütschli, O., '94: Investigations on Microscopic Foams and on Protoplasm (Engl. transl.).

Chamberlain, J. C., '99: Oogenesis in Pinus Laricio. With Remarks on Fertilization and Embryology. Bot. Gaz., vol. xxvii, pp. 268-28I, P1. 4-6.

Coulter, J. M., Chamberlain, J. C., Schaffner, J. H., '97 : Contribution to the Life-History of Lilium Philadelphicum. Bot. Gaz., vol. xxiii, pp. 4I 2-453, Pl. 32-39.

Coulter, J. M., '97 : Notes on the Fertilization and Embryogeny of Conifers. Bot. Gaz., vol. xxiii, pp. 40-43, Pl. 6.

'00: Plant Structures. A Second Book of Botany.

Dixon, H. H., '95 : Fertilization of Pimus sylvestris. Ann. Bot., vol. viii, pp. 2 I$34, \mathrm{Pl} .3-5$.

Farmer, J. B., and Williams, J. Ll., '98: Contributions to our Knowledge of the Fucaceae : their Life-History and Cytology. Phil. Trans. Roy. Soc., Series B, vol. cxc, pp. 623-647, Pl. I9-24.

Fulmer, Edward L., '98 : Cell Division in Pine Seedlings. Bot. Gaz., vol. xxvi, pp. 239-246, Pl. $23^{-24}$.

Golinski, St. J., '93 : Ein Beitrag zur Entwickelungsgeschichte des Androeciums und des Gynoeciums der Gräser. Bot. Centr., Bd. lv, pp. I-I 7, 65-72, I 29-135, Taf. I-3.

Goroschankin, '83 : Ueber den Befr.-Process bei Pinus Pumilio. Strassburg.

Guignard, L., '91 : Nouvelles Études sur la Fécondation. Ann. Sci. Nat., Bot., $7^{\ominus}$ sér., tom. xiv, pp. $163^{-296}$, Pl. 9-18.

'97 : Les centres cinétiques chez les végétaux. Ann. Sci. Nat., Bot., $8^{\circ}$ sér., tom. vi, pp. I77-220, Pl. 9-I I.

'99: Sur les Anthérozoïdes et la double copulation sexuelle chez les végétaux angiospermes. Académie des Sciences, Comptes Rendus, tom. cxxviii, pp. I-8. An abstract, Flora, I899, Bd. Ixxxvi, p. 35 . 
Heidenhain, M., '93: Ueber Kern und Protoplasma. Festschr. z. 50-jähr. Doctorjub. von v. Kölliker. Leipzig.

'94: Neue Untersuchungen über die Centralkörper und ihre Beziehungen zum Kern und Zellenprotoplasma. Archiv für mikroskopische Anatomie, Bd. xliii, pp. 423-759, Taf. 25-31.

Hertwig, R., '98 : Kerntheilung, Richtungskörperbildung und Befruchtung von Actinosphaerium. Abh. k. bayer. Akad. Wiss., Bd. xix, Heft 2.

Hirase, S., '97: Untersuchungen über das Verhalten des Pollens von Ginkgo biloba. Bot. Centr., Bd. lxix, pp. 33-35.

'98: Études sur la fécondation et l'embryogénie du Ginkgo biloba. Jour. of the Col. Sci. Univ. Imp. Tokio, vol. xii, Part II, pp. I03-150, Pl. 7-9.

HoF, A. C., '98: Histologische Studien an Vegetationspunkten. Bot. Centr., Bd. lxxvi, pp. 65-69, I I 3-I I 8, I66-I 7 I, 22 I-226, Taf. 3-4.

Hofmeister, '49 : Die Entstehung des Embryo der Phanerogamen. Leipzig.

'51: Vergleichende Untersuchungen höherer Kryptogamen und der Samenbildung der Coniferen.

'58: Neuere Beobachtungen über Embryobildung der Phanerogamen. Jahrb. f. wiss. Bot., Bd. i, pp. 80-186, Taf. 7-10.

'62 : On the Germination, Development, and Fructification of the Higher Cryptogamia and on the Fructification of the Coniferae.

'67 : Die Lehre von der Pflanzenzelle: Bd. i. Erste Abtheilung des Handbuches der physiologischen Botanik.

Ikeno, S., and Hirase, S., '97 : Spermatozoids in Gymnosperms. Ann. Bot., vol. xi, pp. 344-345.

IKeno, S., '97 : Vorläufige Mittheilung über die Spermatozoiden bei Cycas revoluta. Bot. Centr., Bd. lxix, Heft I, pp. I-3.

'98, 1: Untersuchungen über die Entwickelung der Geschlechtsorgane und den Vorgang der Befruchtung bei Cycas revoluta. Jahrb. f. wiss. Bot., Bd. xxxii, pp. 557-6o2, Taf. 8-1o.

'98, 2 : Zur Kenntniss des sogenannten centrosomähnlichen Körpers im Pollenschlauche der Cycadeen. Flora, Bd. lxxxv, pp. I 5-I8.

JäGER, L., '99: Beiträge zur Kenntniss der Endospermbildung und der Embryologie von Taxus baccata, L. Flora, Bd. lxxxvi, pp. 240-288, Taf. I 5-I9.

Karsten, G., '93 : Ueber Beziehungen der Nucleolen zu den Centrosomen bei Psilotum triquetrum. Ber. d. deutsch. bot. Gesell., Bd. xi, pp. 555563 , Taf. xxix.

Le Dantec, Felix, '99: Centrosome et Fécondation. Académie des Sciences, Comptes Rendus, tom. cxxviii, pp. I34I-I 343 .

MacMillan, Conway, '98: Relationship between Pteridophytes and Gymnosperms. Science, N. S., vol. vii, pp. 16I-I64.

Merrell, W. D., '00: A Contribution to the Life-History of Silphium. Bot. Gaz., vol. xxix, pp. 99-134, Pl. 3-10.

Mottier, D. M., '98: Ueber das Verhalten der Kerne bei der Entwickelung des Embryosacks und die Vorgänge bei der Befruchtung. Jahrb. f. wiss. Bot., Bd. xxxi, pp. I $25^{-1} 5^{8}, \mathrm{Pl} .2-3$. '00: Nuclear and Cell Division in Dictyota dichotoma. Ann. Bot., vol. xiv, pp. 163-192, Pl. II. 


\section{Ferguson.-Development of the Pollen-tube and the}

Nawaschin, S., '99: Neue Beobachtungen über Befruchtung bei Fritillaria tenella und Lilium Martagon. Bot. Centr., Bd. lxxvii, p. 62.

Nemec, B., '98: Ueber die Ausbildung der achromatischen Kerntheilungsfigur im vegetativen und Fortpflanzungs-Gewebe der höheren Pflanzen. Bot. Centr., Bd. lxxiv, pp. I-5. Eight figures.

'99, 1: Ueber die karyokinetische Kerntheilung in der Wurzelspitze von Allium Cepa. Jahrb. f. wiss. Bot., Bd. xxxiii, pp. 31 3-336, Taf. 3. '99, 2 : Ueber Kern- und Zelltheilung bei Solanum tuberosum. Flora, Bd. lxxxvi, pp. 21 4-227. Nine figures.

'99, 3: Zur Physiologie der Kern- und Zelltheilung. Bot. Centr., Bd. lxxvii, pp. 24I-252. Seven figures.

Osterhout, W. J. V., '97 : Ueber Entstehung der karyokinetischen Spindel bei Equisetum. Jahrb. f. wiss. Bot., Bd. xxx, Heft 3, pp. 159-168, Taf. I-2.

Rosen, F., '92 : Beiträge zur Kenntniss der Pflanzenzellen. Cohn's Beitr. z. Biol. d. Pflanzen, Bd. v, pp. 443-458, Taf. I6.

'95 : Beiträge zur Kenntniss der Pflanzenzellen. III. Kerne und Kernkörperchen in meristematischen und sporogenen Geweben. Cohn's Beitr. z. Biol. d. Pflanzen, Bd. vii, pp. 225-3I 2, Taf. 2-4.

SARGANT, E., '99: On the presence of two vermiform nuclei in the fertilized embryo-sac of Lilium Martagon. Proc. Roy. Soc., vol. lxv, pp. I63-165.

Schaffner, J. H., '98: Karyokinesis in the Root-tips of Allium Cepa. Bot. Gaz., vol. xxvi, pp. 22 5-239, Pl. 21-22.

Strasburger, E., '69 : Die Befruchtung bei den Coniferen.

'72: Die Coniferen und die Gnetaceen.

'78: Ueber Befruchtung und Zelltheilung.

'79: Die Angiospermen und die Gymnospermen.

'84: Neue Untersuchungen über den Befruchtungsvorgang bei den Phanerogamen als Grundlage für eine Theorie der Zeugung.

'92: Ueber das Verhalten des Pollens und die Befruchtungs-

vorgänge bei den Gymnospermen. Hist. Beitr.

'00: Ueber Reductionstheilung, Spindelbildung, Centrosomen und Cilienbildner im Pflanzenreich.

Swingle, W. T., '97: Zur Kenntniss der Kern- und Zelltheilung bei den Sphacelariaceen. Jahrb. f. wiss. Bot., Bd. xxx, pp. 297-35I, Taf. I5-16.

Thomas, Ethel N., '00, 1 : On the Presence of Vermiform Nuclei in a Dicotyledon. Ann. Bot., vol. xiv, pp. 318-319.

' 00,2 : Double Fertilization in a Dicotyledon-Calthapalustris, ibid., pp. 527-535, Pl. XXX.

Webber, H. J., '97, 1: Peculiar Structures occurring in the Pollen-tube of Zamia. Bot. Gaz., vol. xxiii, pp. 453-459, Pl. I I.

'97, 2 : The Development of the Antherozoids of Zamia. Bot. Gaz., vol. xxiv, pp. 16-23. Five figures.

'97, 3: Notes on the Fecundation of Zamia and the Pollen-tube Apparatus of Ginkgo. Bot. Gaz., vol. xxiv, pp. $225^{-2} 36$, Pl. Iо.

Wilson, E. B., '99: The Structure of Protoplasm. Science, vol. x, No. 237, pp. 33-44. Nine figures.

'00: The Cell in Development and Inheritance. 


\section{Division of the Generative Nuclens in Pines.}

\section{EXPLANATION OF FIGURES IN PLATES XII, XIII, AND XIV.}

Illustrating Miss Ferguson's paper on the Pollen-tube of Pines.

All figures were drawn by the aid of the Abbé camera lucida, the image being thrown down only $\mathrm{I} 43 \mathrm{~mm}$. A Zeiss microscope was used and (with the exception of Figs. I-5 and 44) the $2 \mathrm{~mm}$. homogeneous immersion objective. This objective was combined with the compensating ocular No. 8 for Figs. $23-43,46$, and $46 b$; for all other figures the compensating ocular No. 4 was used. The figures are reproduced from the drawings without reduction. Throughout the plates the lettering is to be interpreted as follows : third prothallial or antheridial cell $(a . c$.$) ,$ vegetative nucleus $\left(v . n\right.$.), stalk-cell (st. $\left.c_{\text {. }}\right)$, stalk-nucleus (st. $\left.n_{\text {. }}\right)$, generative cell $\left(g . c_{.}\right)$, generative nucleus $\left(g \cdot n_{0}\right)$, sperm-cell $\left(s . c_{.}\right)$, sperm-nucleus $(s . n$.$) ,$ prothallium $\left(P r_{.}\right)$, spongy tissue $\left(s_{.} t_{.}\right)$, archegonium (arch.), and starch grains (s. g.).

\section{PLATE XII.}

Fig. I. A vertical section through an ovule some days after pollination; $A$. $r$., axial row; $p . g$. , pollen-grain. $\times 70$. Pinus Strobus, June 17 .

Fig. 2. A vertical section of an ovule showing the winter condition. $\times 70$. Pinus Strobus, Jan. 4.

Fig. 3. A vertical section of an ovule soon after the second period of growth has begun. $\times 70$. Pinus Strobus, May 26.

Fig. 4. A vertical section through the upper part of an ovule at the time of the division of the generative nucleus; $n . c . I$, that portion of the nucellar cap which was developed during the first period of activity; n.c. 2 , that part of the nucellar cap which constitutes the second year's growth; 0 , disintegrating spongy tissue. $\times$ 70. Pinus Strobus, June 9 .

Fig. 5. A vertical seetion through the upper part of an ovule shortly before fertilization; $e . n$., egg nucleus; 0 , last vestige of spongy tissue. $\times 70$. Pinus Strobus, June I5.

Fig. $5 b$. Pollen-grain from the nucellus of Fig. 5 . The antheridial cell is still undivided. $\times 540$.

Fig. 6. Mature pollen-grain; $p .{ }^{1}$, first prothallial cell ; $p{ }^{2}$, second prothallial cell. $\times$ 540. Pinus Strobus, June 8.

Fig. 7. A vertical section through the extreme upper portion of an ovule soon after pollination, showing the uppermost part of the nucellar cap, and a pollengrain in the first stages of germination; $P . c$., pollen-chamber. $\times 54^{\circ}$. Pinus Strobus, June I3.

Fig. 8. A pollen-grain soon after germination; $\not .^{2}$, second prothallial cell. $\times 540$. Pinus Strobus, June 24 .

Fig. 9. A pollen-grain after the vegetative nucleus has passed into the pollentube. $\times$ 540. Pinus Strobus, July I 5 .

Fig. Io. A pollen-grain after the antheridial cell has divided. $\times 540$. Pinus Strobus, Aug. 4 . 


\section{Ferguson.-Development of the Pollen-tube and the}

Fig. II. The same at a later date, showing a slight increase in the size of generative cell. $\times$ 540. Pinus Strobus, Oct. 7 .

Fig. I2. The pollen-tube which is shown in Fig. 2, more highly magnified. $\times$ 540. Pinus Strobus, Jan. 4 .

Fig. I3. A pollen-grain and the upper portion of a pollen-tube, showing the stalk- and the generative cell just before their passage into the pollen-tube. $\times 54$. Pinus austriaca, May 3.

Figs. I4 and I5. Later stages than the above, showing the passage of the generative and the stalk-cell into the pollen-tube; in Fig. I5 the two cells are breaking loose from each other. $\times 54$. Pinus austriaca, May Io and 17 .

Fig. I6. The male gametophyte at the time of the entrance into the tube of the generative and the stalk-cell; $n . t .$, a bit of the dead nucellar tissue. $\times 54$ o. Pinus Strobus, June 9.

Fig. I7. A pollen-grain after the generative and the stalk-cell have passed into the pollen-tube; taken from the top of the nucellus of Fig. $4 . \quad \times 540$. Pinus Strobus, June 9.

Fig. 18. A few of the cells from that portion of the nucellar cap marked n.c. 2 in Fig. 4. The cells are filled with starch-grains. $\times$ 540. Pinus Strobus, June 9.

\section{PLATE XIII.}

Figs. I9-2I. Portions of pollen-tubes showing successive stages in the passage of the stalk-cell over the generative cell, as also the presence of large quantities of starch in the pollen-tube. $\times 54^{\circ}$. Pinus resinosa, June $2 ; P$. Strobus, May 24 ; P. rigida, June 8.

Fig. 22. The generative cell, bearing on its surface both the vegetative and stalk-nuclei. In this instance the stalk-cell has passed beyond the vegetative nucleus. $\times 540$. Pinus resinosa, June 3 .

Figs. 23-25. The generative cell in the early stages of its division, showing granular condensation and radial arrangement of cytoplasm. $\times 850$. Pinus rigida, June 8 and ro.

Fig. 26. A later stage of the same. $\times 850$. Pinus austriaca, June 10.

Fig. 27. The generative cell just before the disappearance of the lower portion of the nuclear membrane. $\times 85^{\circ}$. Pinus Strobus, June 9.

Figs. 28 and 28 b. Two sections through the same generative cell. In Fig. 28 the section was cut through the edge of the nucleus and shows the spindle-fibres passing over the outside of it. Fig. $28 b$ represents a section nearer the middle of the nucleus : the nuclear wall has given way at the centre and is fading out along the entire lower portion of the nucleus; some spindle-fibres are entering the nuclear cavity, while others stretch along the surface of the disintegrating membrane. Neither section was cut parallel to the major axis of the growing spindle. $\times 85^{\circ}$ Pinus austriaca, June Io.

Fig. 29. A stage in spindle-formation directly following that shown in Fig. 27. $\times 85^{\circ}$. Pinus Strobus, June Io.

Figs. 30-35. Later stages in the development of the spindle, showing the gradual drawing together of the outer extremities of the threads to form the upper pole of the spindle, as also the origin of the chromosomes. $\times 850$. Fig. 33, Pinus rigida, June I 3 ; the other figures, Pinus austriaca, June $7-10$.

Fig. 36 . A cross-section through the generative cell during an early stage in its 


\section{Division of the Generative Nucleus in Pines.}

mitosis. The protoplasmic condensation is seen from below looking toward the nucleus. $\quad \times 980$. Pinus austriaca, June 4 .

Fig. 37. The sperm-nuclei just after their formation. $\times 850$. Pinus montana, var. uncinata, May $3 \mathbf{I}$.

\section{PLATE XIV.}

Figs. 38-43. Various stages in the formation of the daughter-nuclei. $\times 850$. Figs. 38 and $43, P$. Strobus, June 9 and Io; Fig. 39, P. resinosa, June I 5 ; Figs. 40 and $42, P$. austriaca, June Io. Fig. 4 I represents another section through the upper nucleus of Fig. 40, and shows how the upper of the sperm-nuclei is frequently indented along its outer surface.

Fig. 44. This pollen-tube, having approached an egg that had already been fertilized, has turned aside and is passing up over the endosperm so that the normal position of the cells appears exactly reversed; $n$. a., neck-cells of the archegonium. $\times$ 330. Pinus Strobus, June 20.

Fig. 45. The generative cell and another nucleus, not the stalk-nucleus, just passing into the pollen-tube. $\times 540$. Pinus Strobus, May 20.

Figs. $4^{6}$ and $46 b$. Cross-sections through the two sperm-nuclei after they have attained full size and have about reached, in their downward passage, the middle of the nucellar cap. $\quad \times 850$. Pinus Strobus, June I 5.

Fig. 47. The sperm-cells after all traces of the spindle have disappeared, but before the two nuclei have come together. $\times 540$. Pinus Strobus, June I3.

Fig. 48. The same after both nuclei have come to lie in the upper part of their cytoplasm. $\times 540$. Pinus Strobus, June Io.

Fig. 49. Lower portion of a pollen-tube which has penetrated about two-thirds the length of the nucellar cap. $\times 540$. Pinus Strobus, June I4.

Fig. 50. Lower portion of a pollen-tube which is just pushing between the neckcells of the archegonium. $P$, pit in apex of tube. $\times 54^{\circ}$. Pinus Strobus, June 20.

Fig. 5 I. A pollen-grain showing an increase in the normal number of nuclei. $\times$ 540. Pinus austriaca, May I 7 .

\section{CORNELL UNIVERSITY, July I, 1900.}




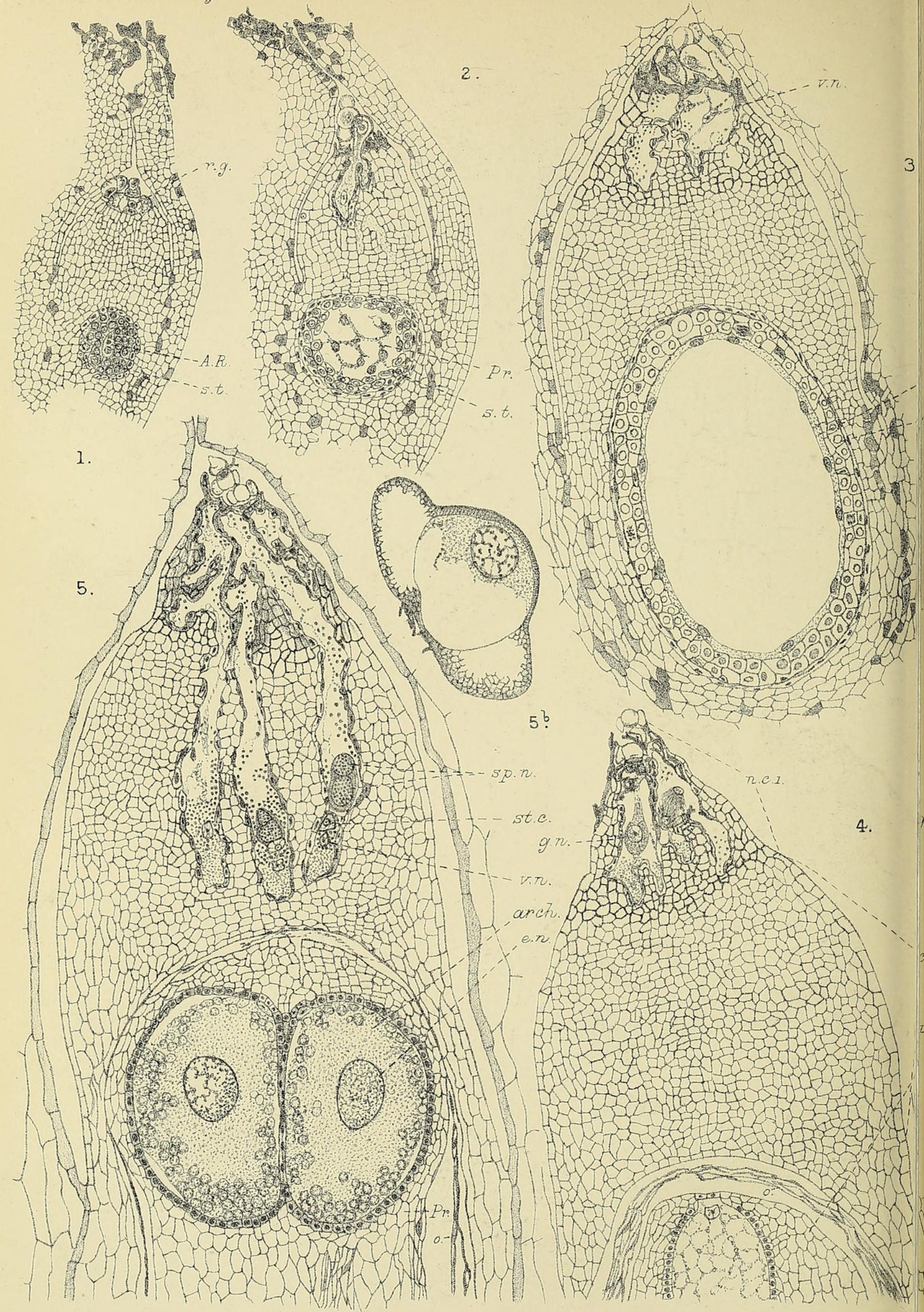


Vol. XV.PL.XII.

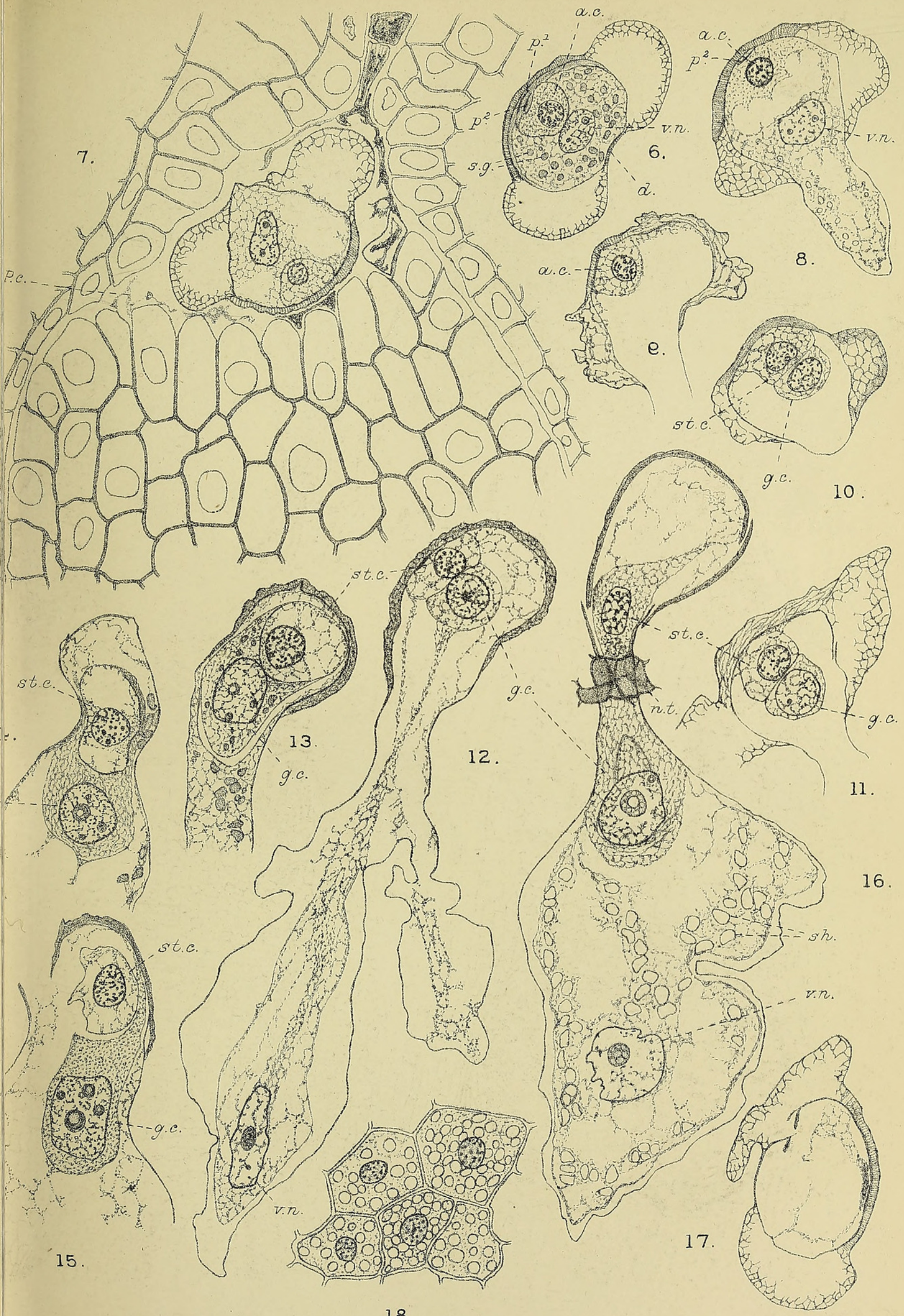

18.

University Press Oxford 
Annals of Botany.
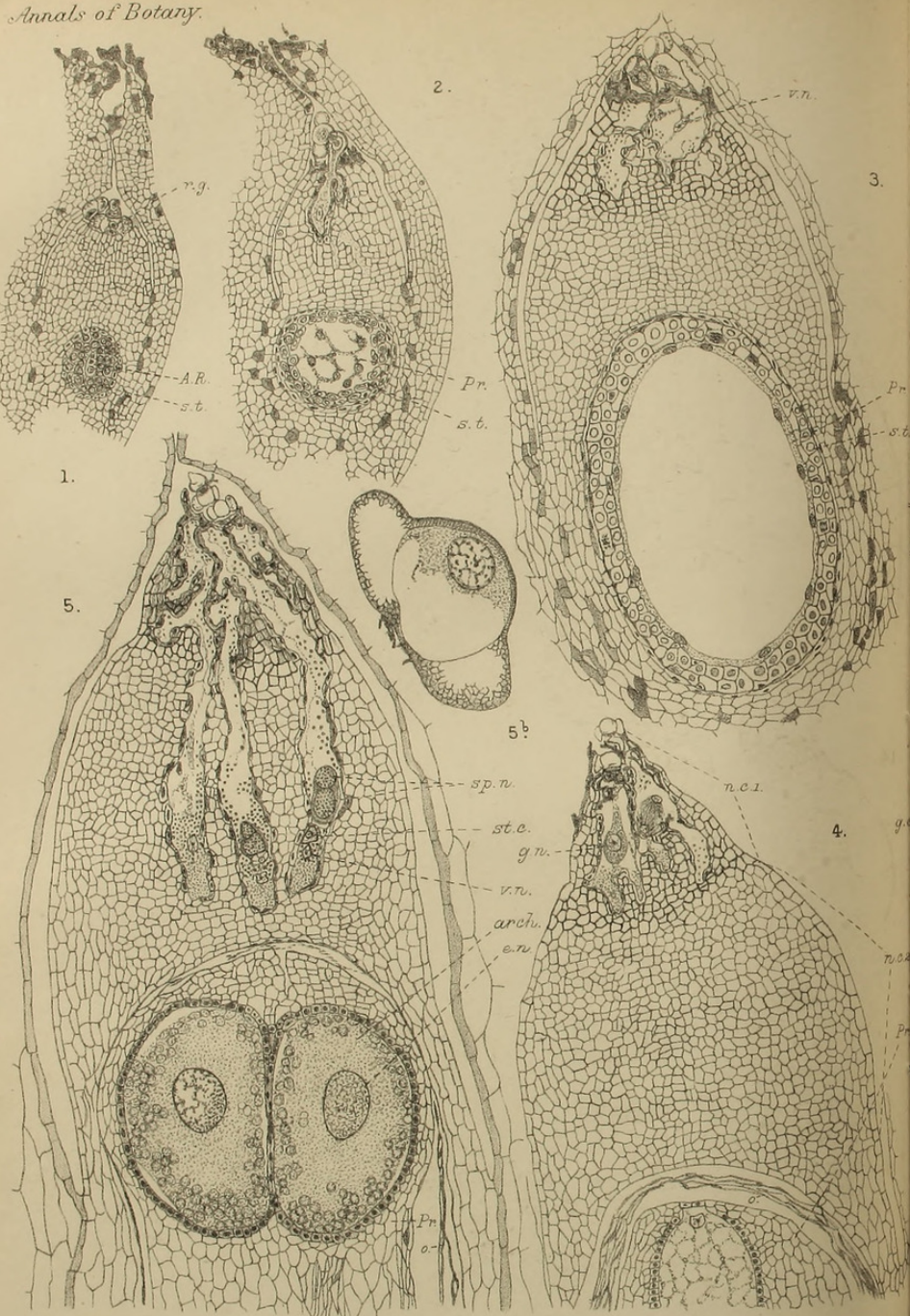

M.C. Ferǵuson del.
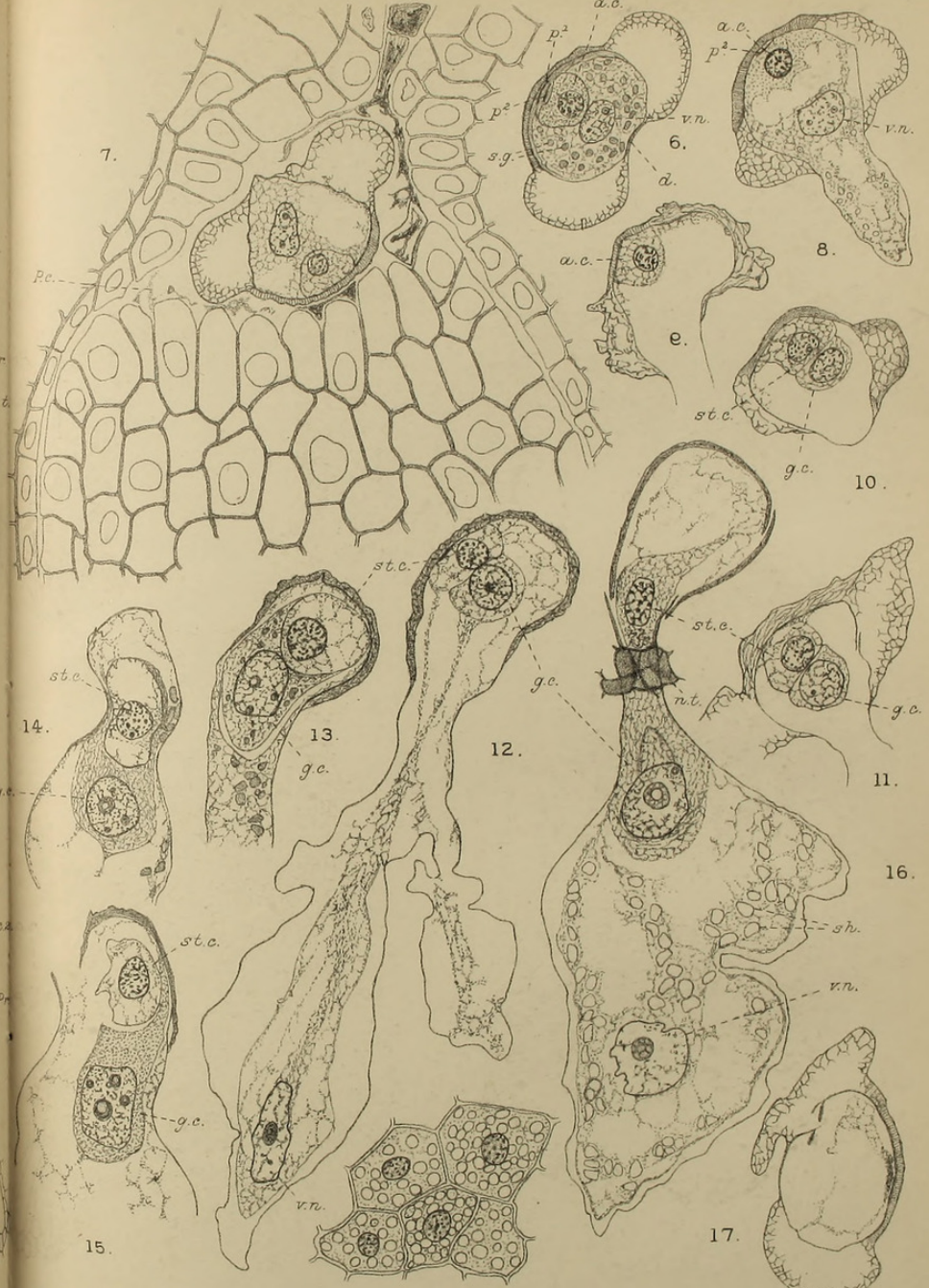

18 .

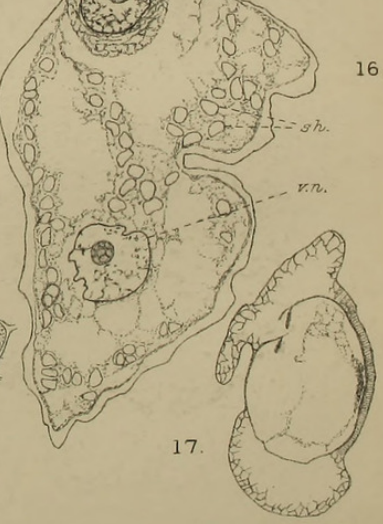

FERGUSON-POLLEN TUBE OF PINUS. 


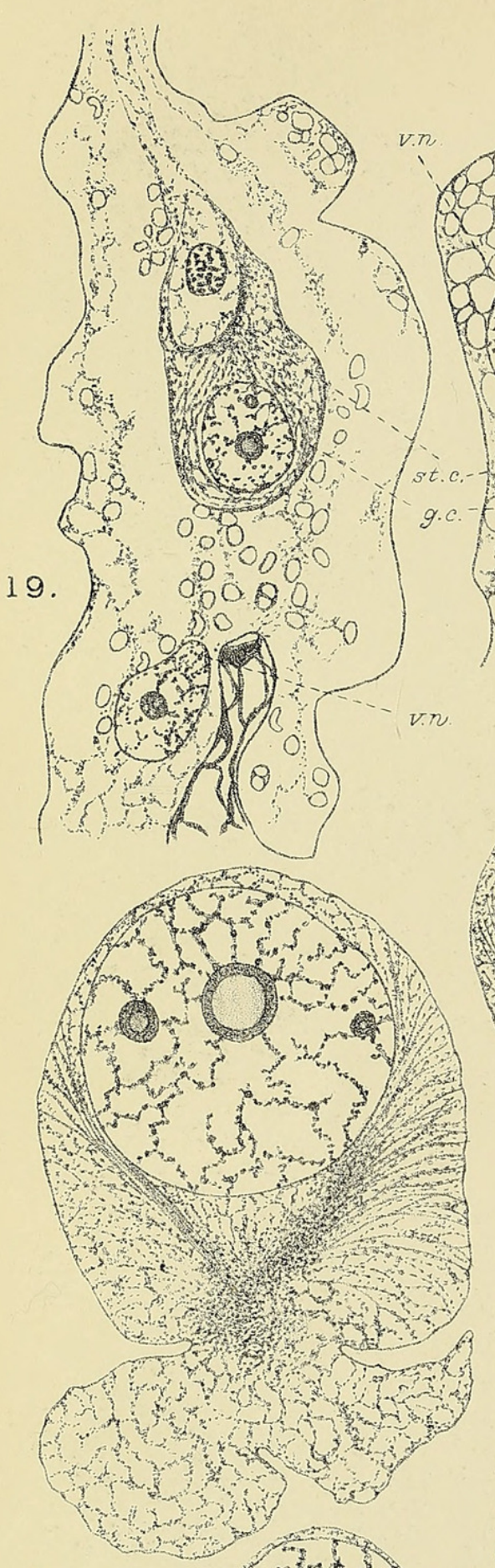

23

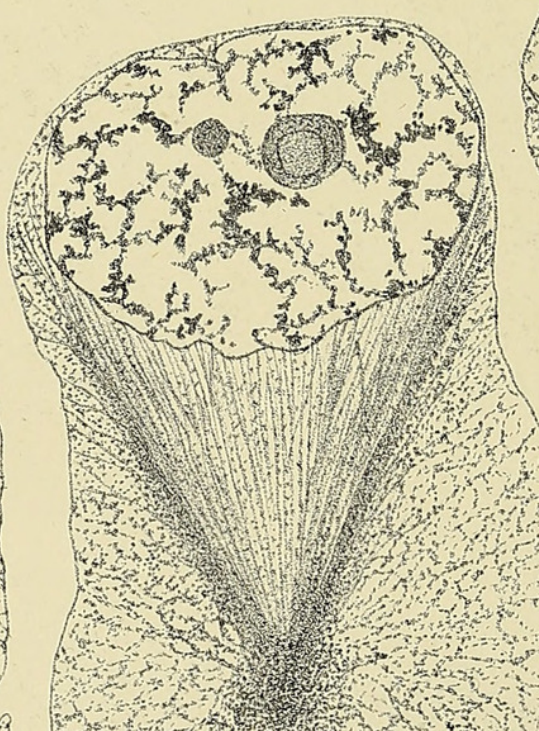

somang a

21.

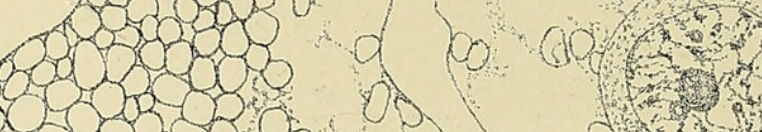
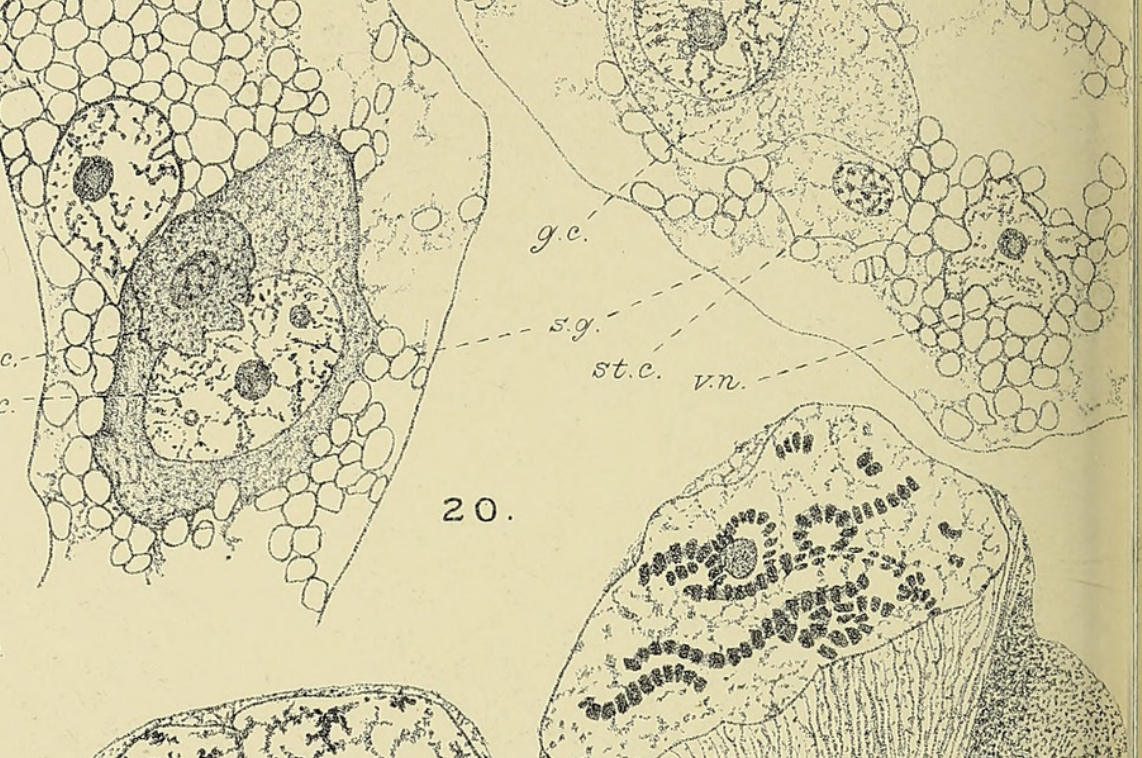

$2 \pi$ a
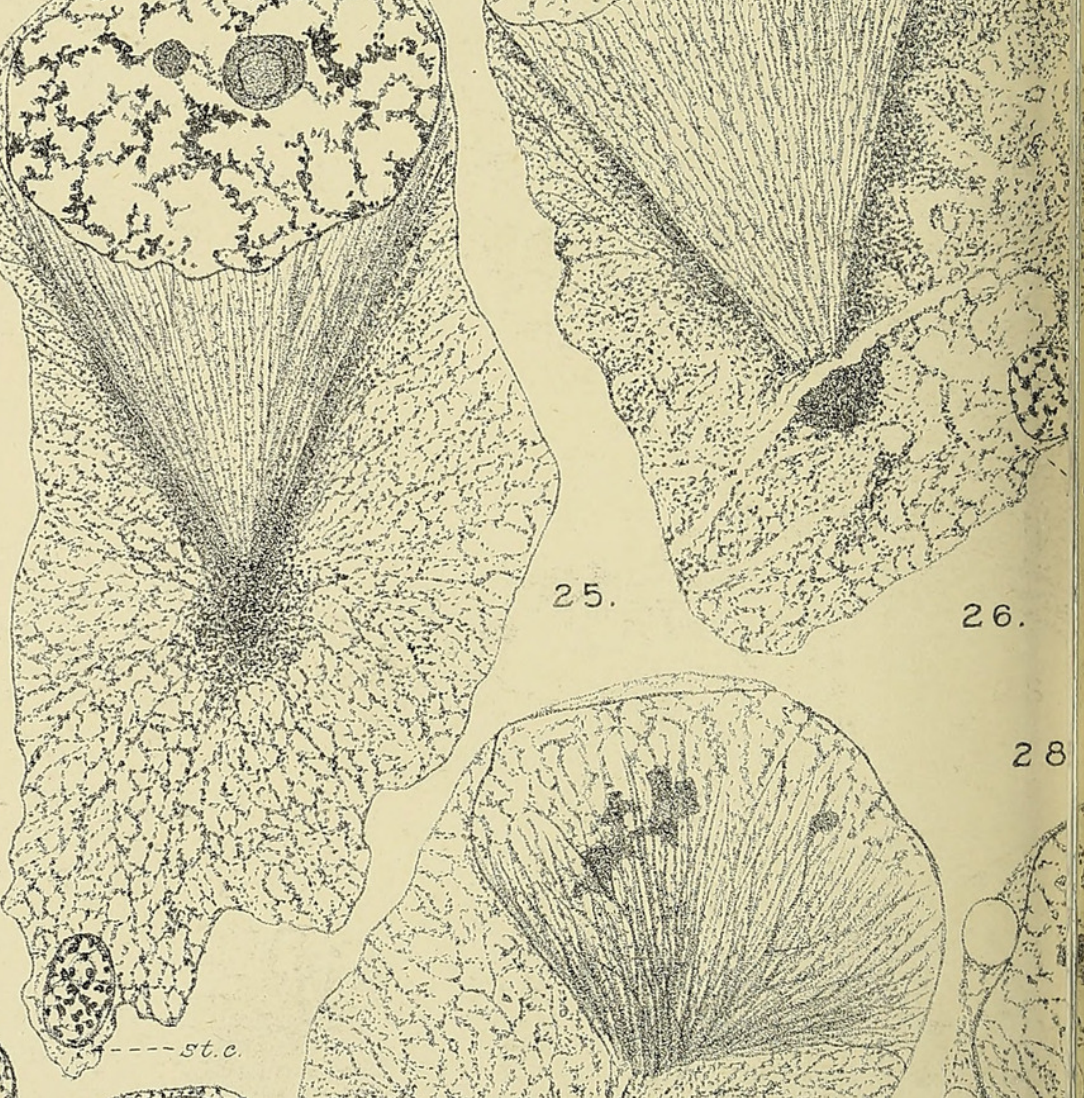

Now W W

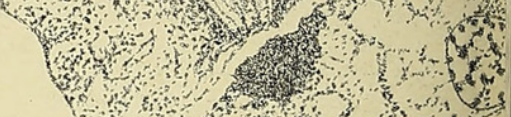

on

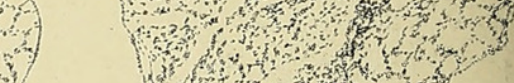

25.

(1)

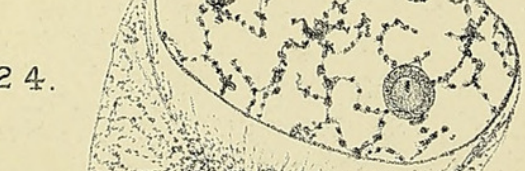

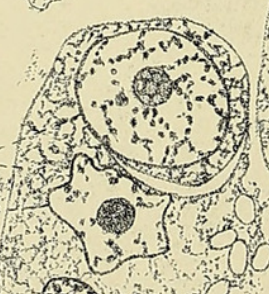

$(8)$

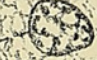

22 

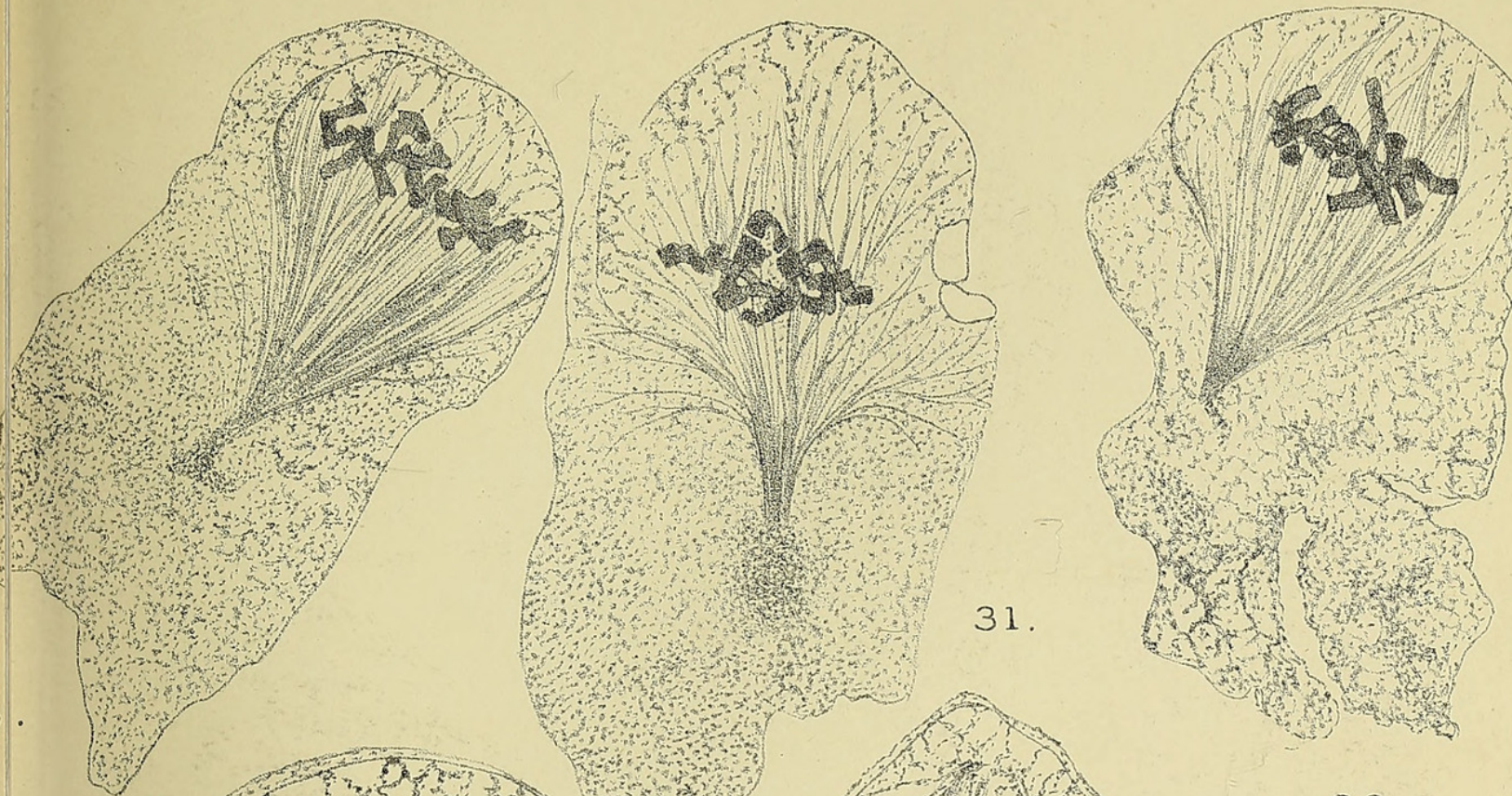

$3,1+2 x^{2}$

$14(4,5)$

(n)

\section{in}

4. 1 (1)

$x_{i \rightarrow \infty}$

\section{Gove}

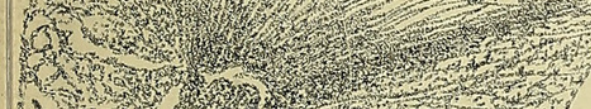

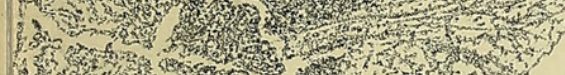

W

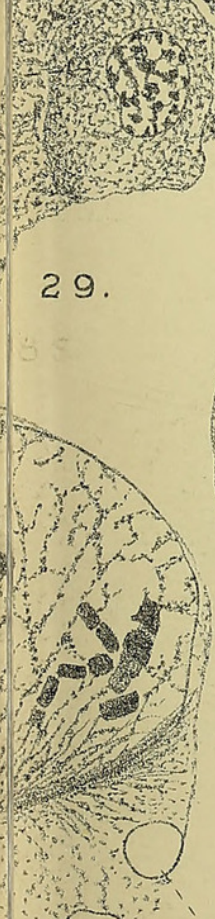

(

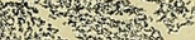

(1)

3 int 4

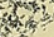
36.

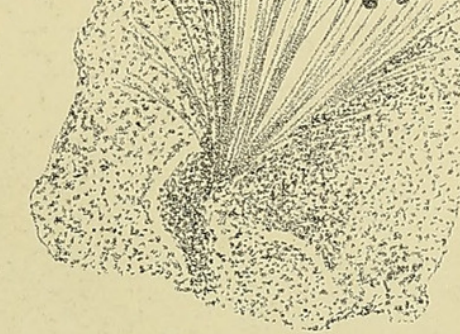

(4)

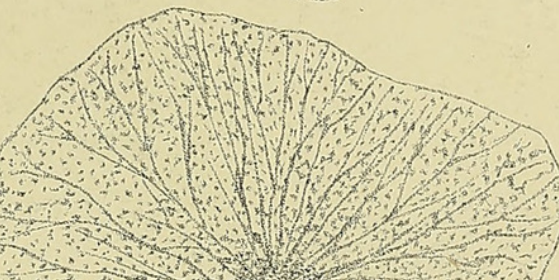

33

32.

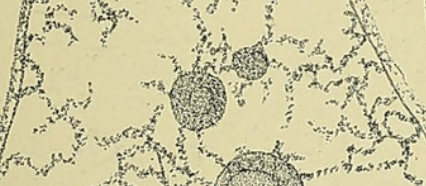
(n)

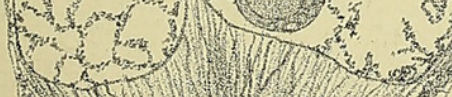

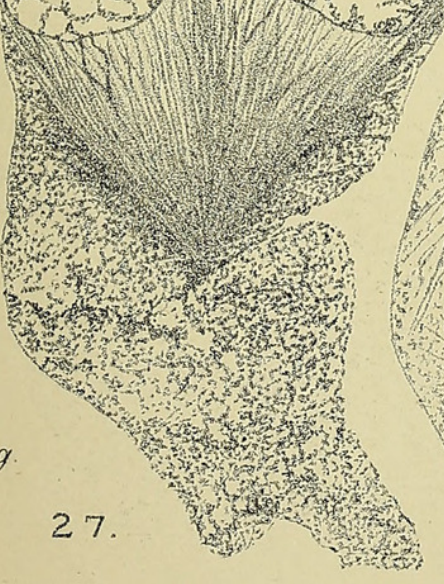
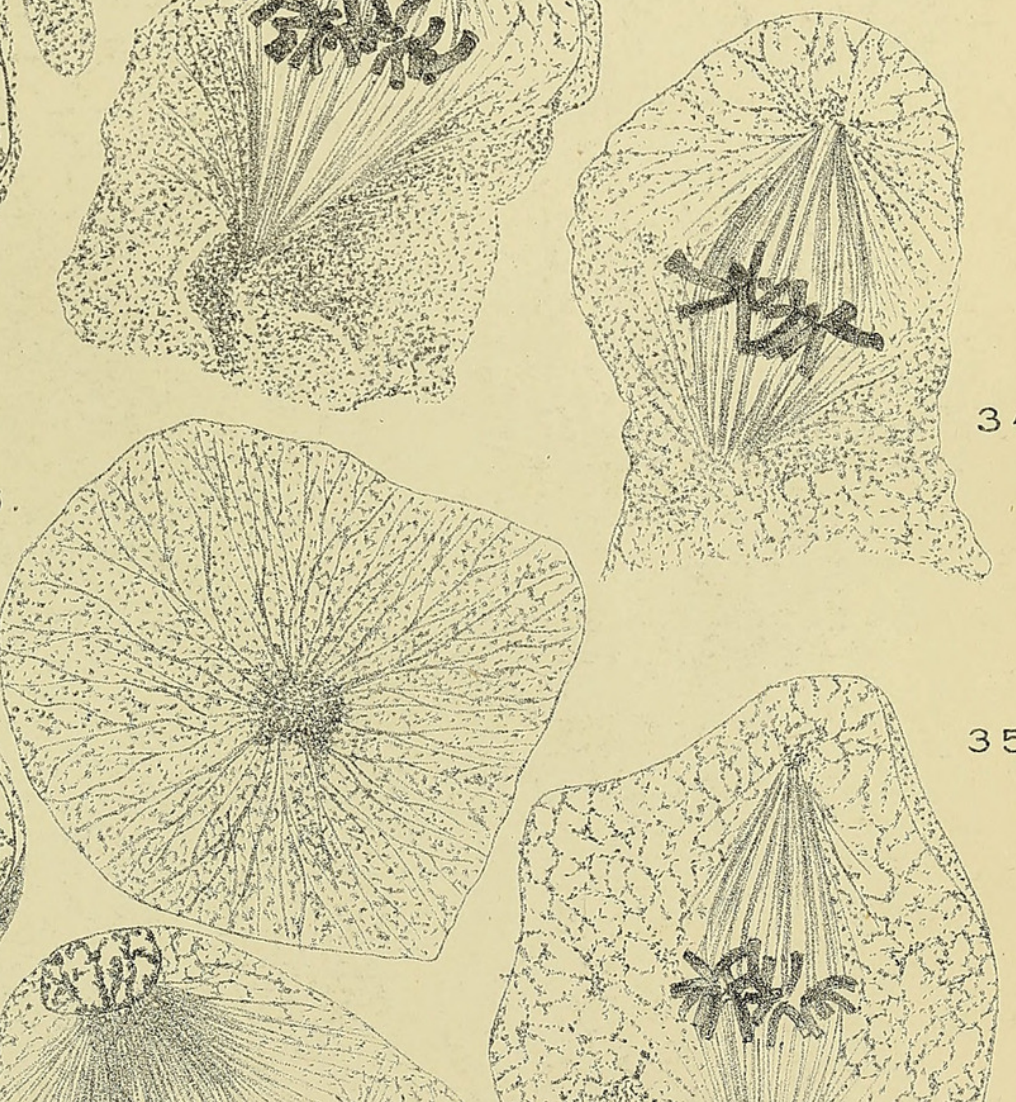

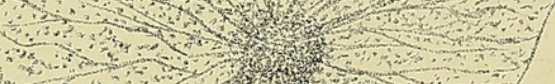

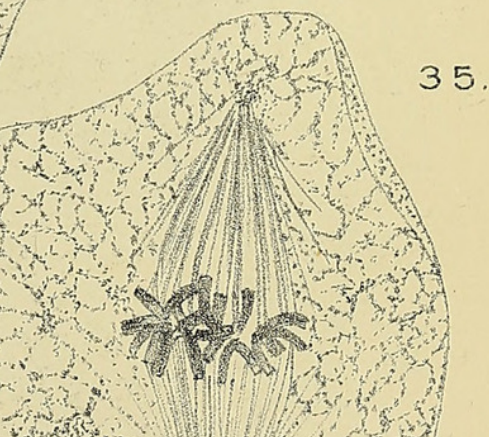



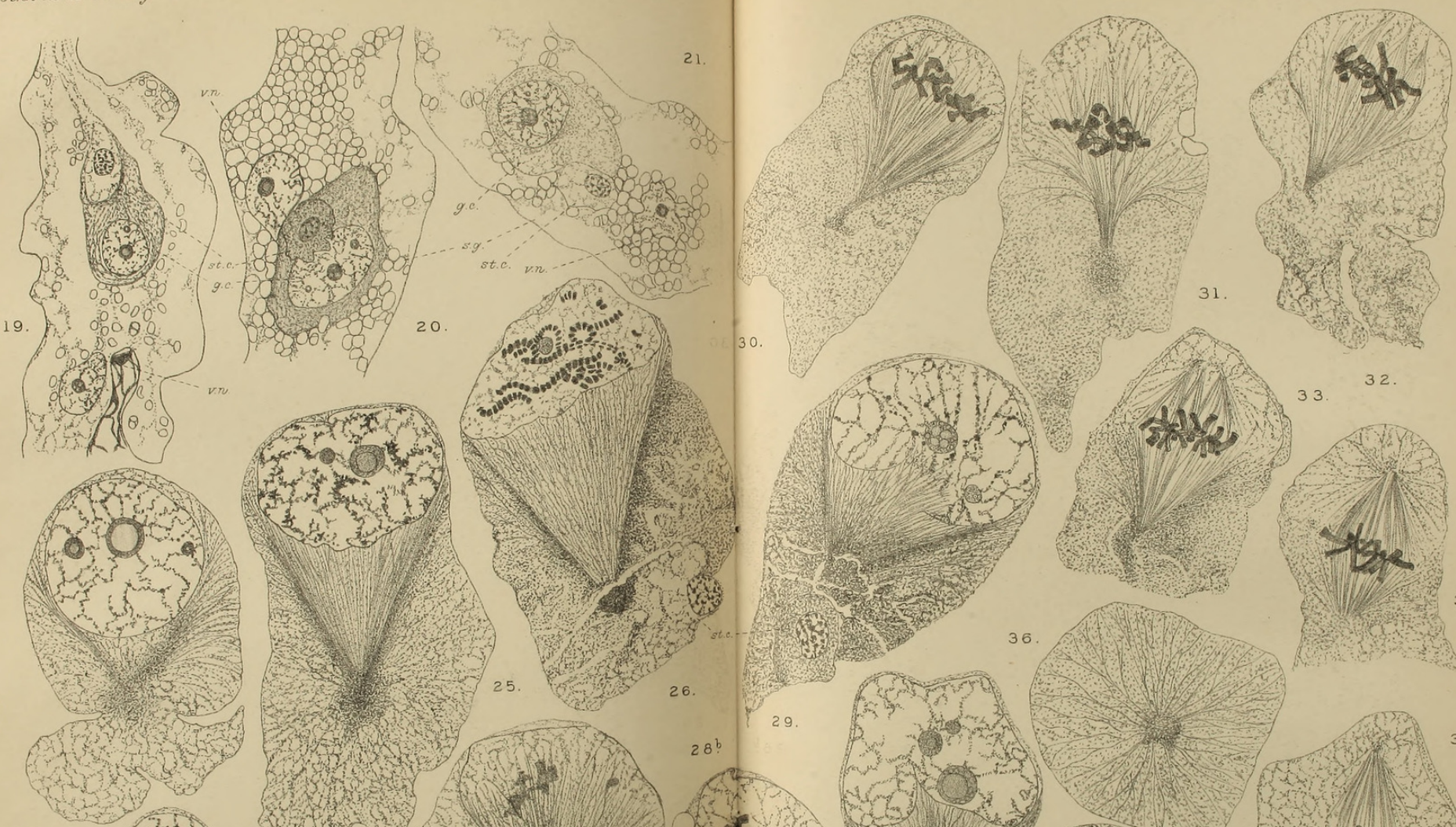
$9800 \%$

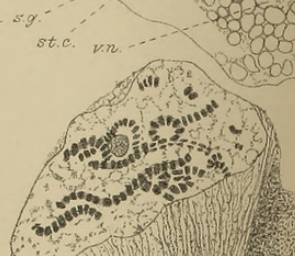

2
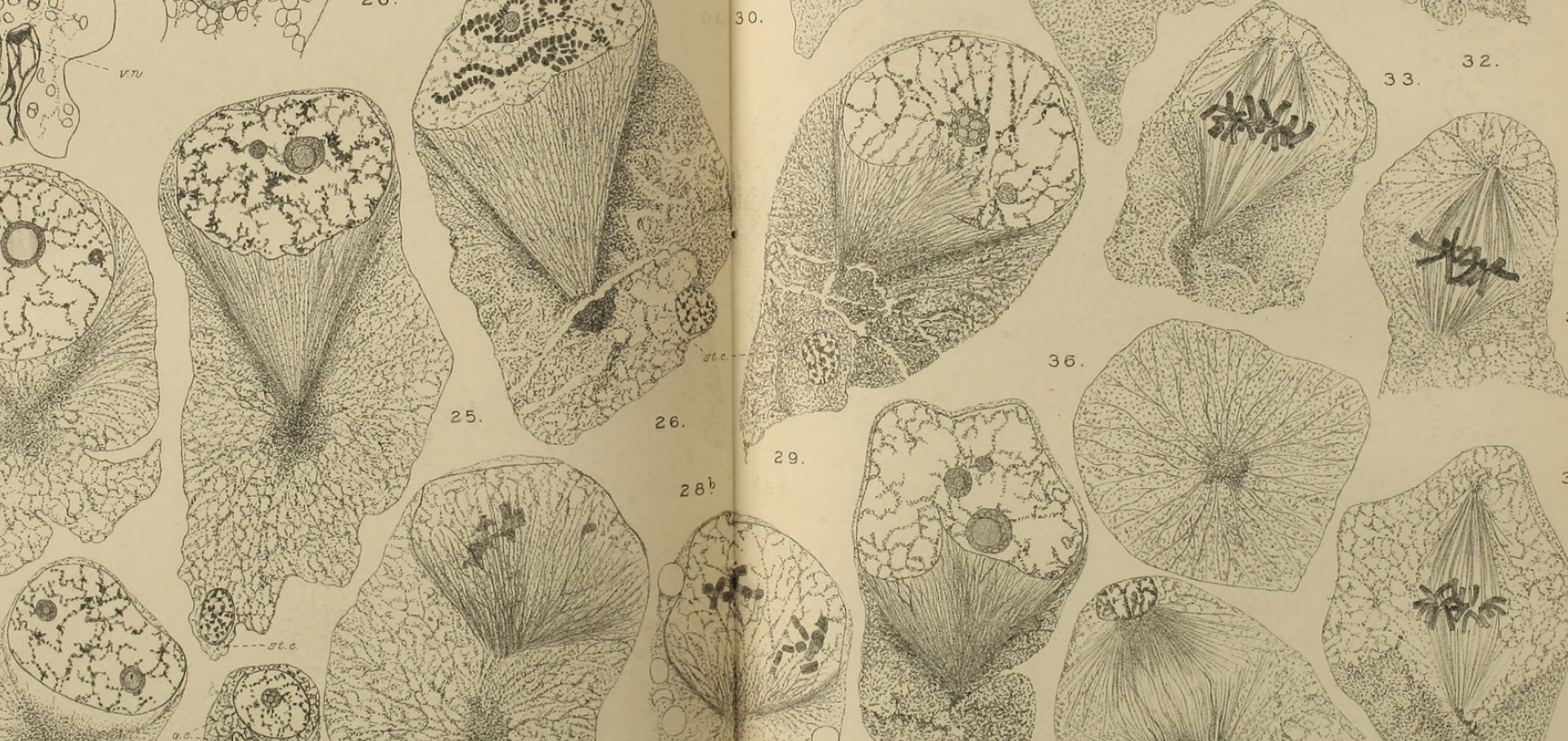

N2.

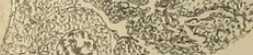

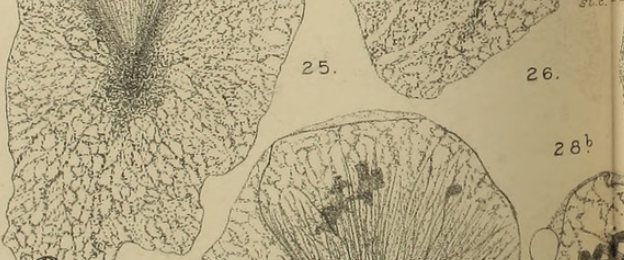

it $h$ in

$y^{3}$
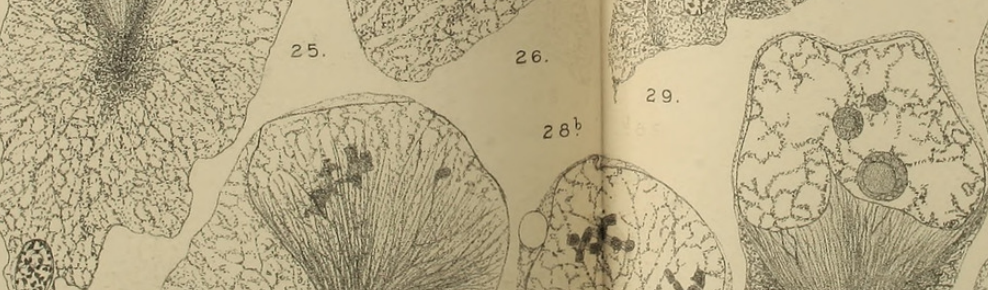

(3)

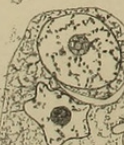

2.t.
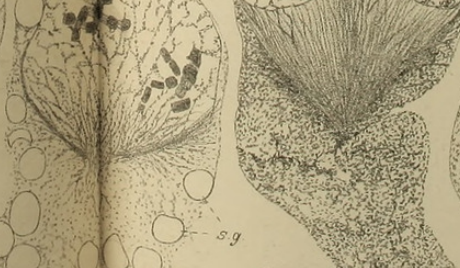

3nd now

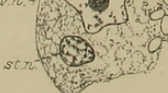

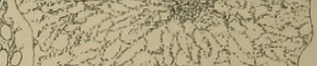

M.C.Ferguson dent

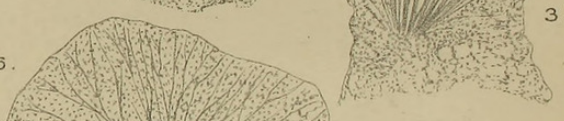


Annals of Botany.

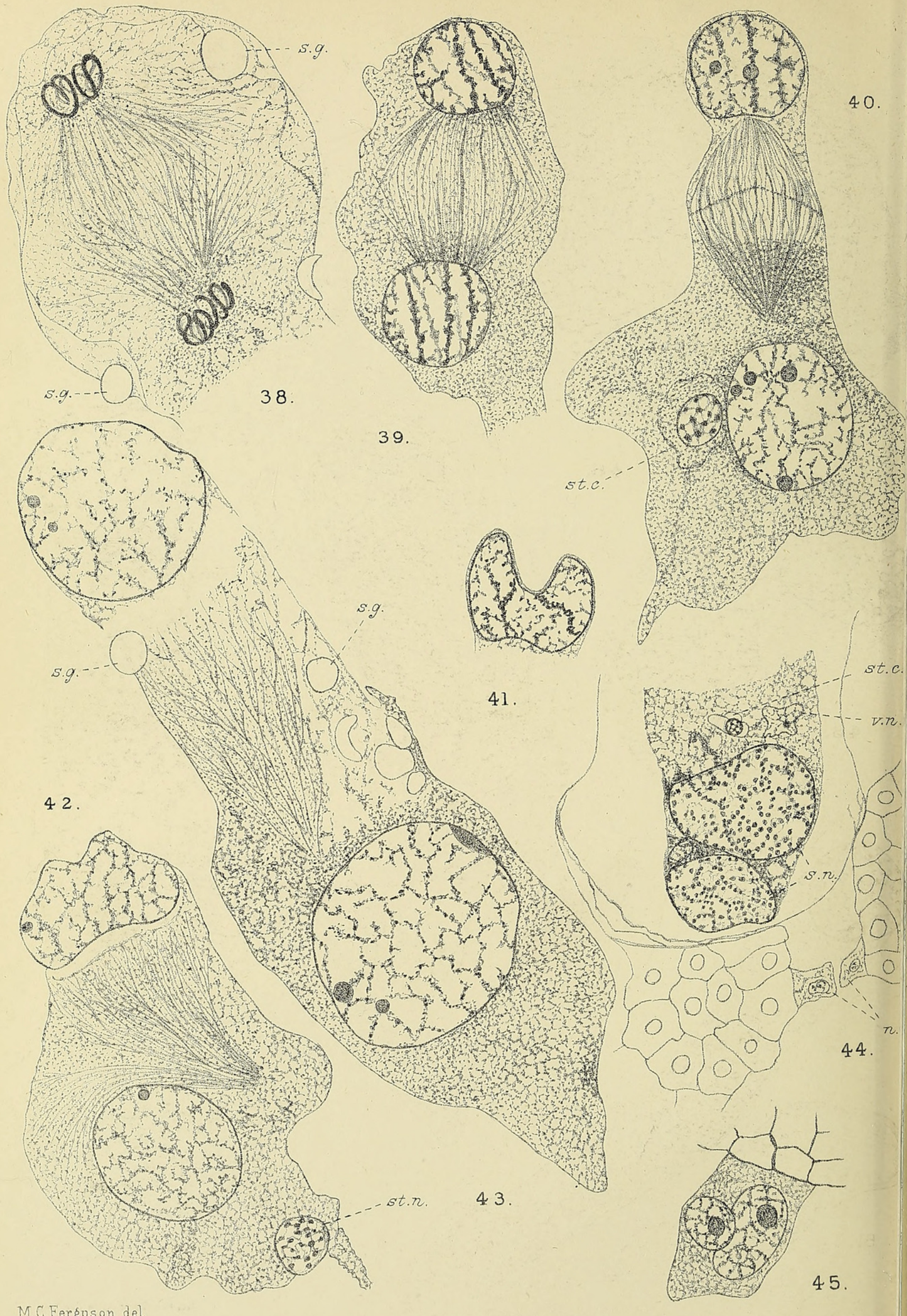

M.C.Fergus on del. 


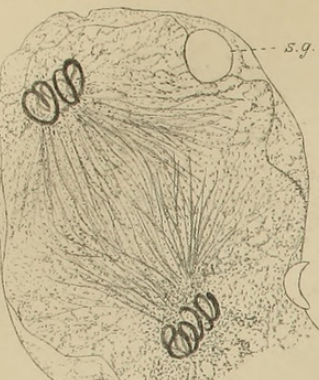

s.... 38

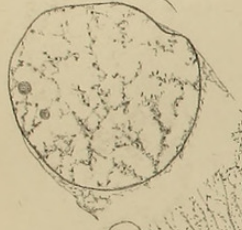

sg... 040

42 .
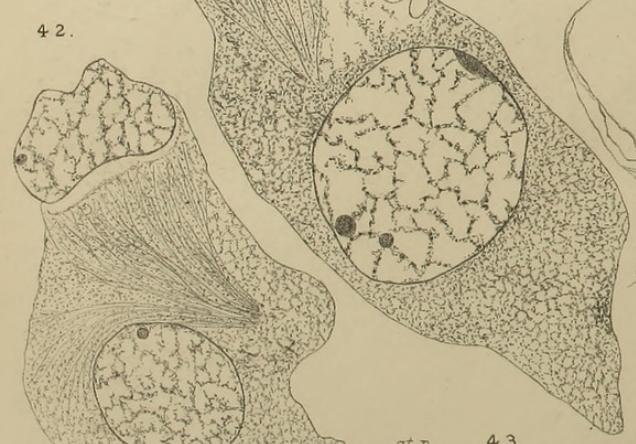

$+x^{2}+3$

$(x)(3)$

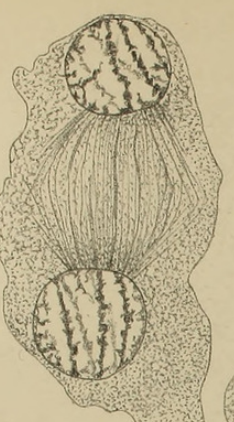

39. s.g.

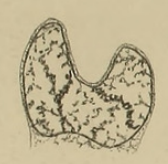

41

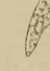

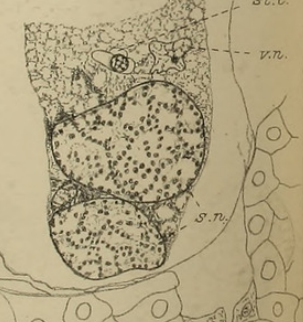
, 0 (a) 0 )
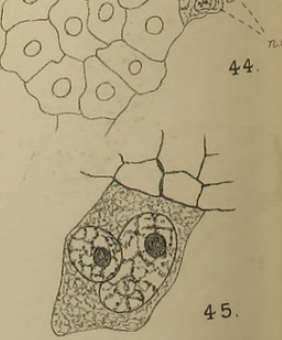

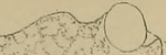

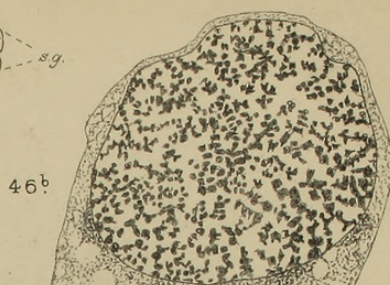

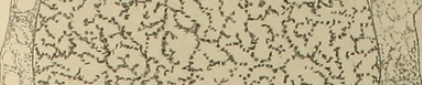

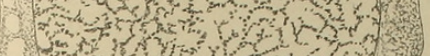

+

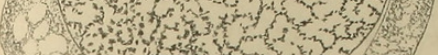

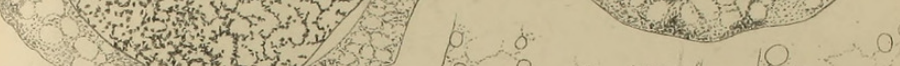$$
\text { (1) }
$$

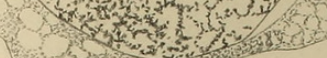
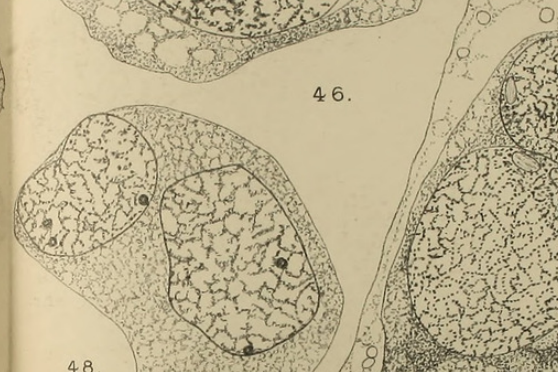

48.

ris

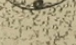

. 12

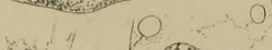

.

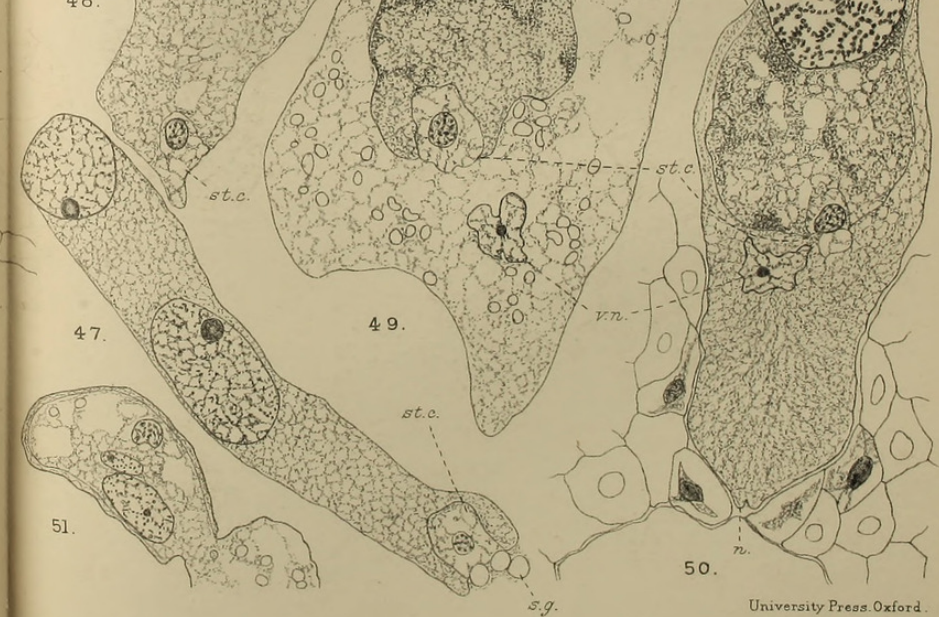




\section{$2 \mathrm{BHL}$ Biodiversity Heritage Library}

Ferguson, Margaret Clay. 1901. "The development of the pollen-tube and the division of the generative nucleus in certain species of pines." Annals of botany 15, 193-223. https://doi.org/10.1093/oxfordjournals.aob.a088817.

View This Item Online: https://www.biodiversitylibrary.org/item/236929

DOI: https://doi.org/10.1093/oxfordjournals.aob.a088817

Permalink: https://www.biodiversitylibrary.org/partpdf/318621

\section{Holding Institution}

Smithsonian Libraries

\section{Sponsored by}

Biodiversity Heritage Library

\section{Copyright \& Reuse}

Copyright Status: Not in copyright. The BHL knows of no copyright restrictions on this item.

This document was created from content at the Biodiversity Heritage Library, the world's largest open access digital library for biodiversity literature and archives. Visit BHL at https://www.biodiversitylibrary.org. 